\title{
MONOLITH IN A HOLLOW: \\ PALEOFUTURISM AND EARTH ART IN \\ STANLEY KUBRICK'S 2001: A SPACE ODYSSEY
}

\section{Jacob Wamberg}

\begin{abstract}
This article analyses 2001 in terms of what I term paleofuturism. Fusing deep future and deep past, this cyclical figure reconciles rational machinic intelligence with diverse repressed temporal layers: archaic cultures, the embryonic state of individuals, and bygone biological and geological eras. In 2001, paleofuturism is nourished by Nietzsche's Übermensch of the future, reborn as a child, and by Jungian ideas of individuation, the reconciliation with the shadow of the collective unconscious that leads to the black cosmos itself. Further paleofuturist contexts for 2001 are explored in the so-called "ancient astronaut thesis" of science fiction, speculative science, and pseudo-science. Finally, in minimalism and earth art of the late 1960s we meet a structural parallel to 2001 's bypassing of the organic human body, one that bridges the inorganic entropic realities of deep future and deep past.
\end{abstract}

\section{KEYWORDS}

Stanley Kubrick, Earth Art, Minimalism, Paleofuturism, Entropy, Evolution, Robert Smithson

\section{INTRODUCTION:}

SKELETONS IN THE CLOSET OF EVOLUTIONARY PROGRESS

A bone-club hurled triumphantly into the air by an African hominid, then transforming into a satellite in outer space: it is difficult to imagine a more explicit allegory of the ambivalence towards evolutionary progress than the famous match cut in 2001: A Space Odyssey (1968). Though now encased in shiny metal and driving automatically through a vacuum, the equipment of the space age is no more than a slight refinement of the bones that made killing animals (for food) and members of one's own species (for power) the condition of a new leap in evolution. Catalysed, as we will see, by the recent discoveries of Australopithecus remains in South Africa, the "Roomful of Bones" that Robert Ardrey interpreted as a sign of animal skeletal parts used as weapons, this 
match cut implies that, indeed, there are skeletons in the closet of evolutionary progress. ${ }^{1}$ In the September 1968 issue of Artforum, published just five months after the premiere of Kubrick's evolutionary fable, and seemingly without influence from it, the artist Robert Smithson was on a related track when he unfolded the ideas behind the brand-new trend of "Earth Projects" (what were later to become "earthworks," "land art,” or, as I prefer to call it here, "earth art"). In a striking parallel to 2001's juxtaposition of deep past and future artefacts, Smithson remarked, "Even the most advanced tools and machines are made of the raw matter of the earth. Today's highly refined technological tools are not much different in this respect from those of the caveman."2 But whereas Kubrick's match cut is symptomatic of a highly ambivalent attitude to mankind's prospects that re-expose the past in the future, one hovering between technological optimism and ethical pessimism, Smithson excludes ethical anxieties to instead celebrate the obsolescence of progress, the future turning into, in Vladimir Nabokov's words, "the obsolete in reverse.”3

In this article, I show that Kubrick's film and Smithson's earth art foreground different sides of the same paradigm, one in which the deep past and the deep future become entangled through continuities and mirroring, and which I therefore term paleofuturist. With what could be posited as a graphic peak in the 1960s, but widely traceable in modern philosophy, art, scienc and popular culture, paleofuturism implies that the more we proceed into a future of advanced technology, disembodied subjects, and rational information, the more we seem to re-actualise all kinds of deep and repressed pasts: archaic cultures, bygone biological and geological eras, and the embryonic state of individuals. The 1960s may present this tendency particularly intensely because it fuses two of this decade's seemingly antagonistic trends: a strong optimism regarding the potential of civilisation's most advanced technology, supported by the period's economic boom, on the one hand; and on the other hand, an equally strong rebellion against all sorts of bourgeois authority-embodied by the Hippie movement, student revolts, the civil rights movement, women's liberation, and avant-garde dissolutions of the autonomous artwork-each with its implications of a simplified and ultimately more primordial way of living.

We may discern an early manifestation of a paleofuturist sensibility in 2001's central literary impetus, Nietzsche's philosophical novel, Also sprach Zarathustra (1883-85), in which the overman of the future is compared to a child, a conception 
that is radicalised in 2001's final images of the reborn human appearing as a foetus in outer space. I will demonstrate that the idea of turning the inorganic black universe itself into a womb with which the reconceived human reunites is more specifically derived from Carl Gustav Jung, whose individuation, the unification with the collective unconscious, Kubrick gives a posthuman evolutionary promise. However, before the initiate to the Star Gate, David Bowman, reaches this stage of paleofuturist fulfilment, the astronauts and their main instrument, the supercomputer HAL 9000, are trapped in a typical Kubrickian field of weak and ambiguous appearances of the inhumanpreconscious aggressive drives and, especially, post-conscious alienating rules, whose meticulous portrayal in 2001 amounts to a thorough critique of rationality.

The wave of paleofuturist desires in which 2001 participates comprises a surprising blend of science fiction, science, pseudoscience, Cold War paranoia, and New Age hopes. In scientific and popular speculation on extra-terrestrial intelligence (Ordway and MacGowan, Shklovskii and Sagan, von Däniken, Hergé), and in their sources and parallels in science fiction (Lovecraft, Clarke, Kneale, Taine, Ballard), archaic monuments may suddenly appear as futuristic technology, and vice versa. 2001 joins earth art and its point of departure, minimalism, as selective high-art responses to these trends. As it appears in its raw, stony hollow in either primordial Africa or on a futuristic moon, the black monolith, 2001's central symbol and catalyst of evolutionary leaps forward, resembles something that could have been created by earth artists and minimalists such as Smithson, Michael Heizer, Dennis Oppenheim, or Sol LeWitt. What binds 2001 to these art movements, deepening the paleofuturist constellation, is a common anti-anthropocentrism that bypasses the organic human body, and a shared preference for the inorganic that could be approached through Smithson's key concept of entropy, a sort of collapsed sublime.

\section{ACCELERATED PROGRESS AND ITS DISCONTENTS:}

\section{NIETZSCHE TO JUNG}

When I suggest paleofuturism as a paradigmatic label for 2001: A Space Odyssey, it is because its temporality seems suspended between an almost manic belief in cognitive progress, and an awareness that such progress somehow involves the recurrence of deep, even suppressed, pasts. The progressive side of paleofuturism is expressed in one of Kubrick's interview comments on the film, 
in which the astronaut, David Bowman, is expressly described as reborn as "an enhanced being, a star child, an angel, a superman, if you like, and returns to the earth prepared for the next leap forward of man's evolutionary destiny." 4 As clearly signalled by 2001's opening sequence, the artificial sunrise created by the camera surging upwards behind moon, earth and sun, and sustained by the ecstatic overture to Richard Strauss's tone poem, Also sprach Zarathustra (1896), the material for this view of evolutionary progress is derived from Nietzsche's identically titled philosophical novel about man's transformation into overman. As Zarathustra states:

All creatures so far created something beyond themselves: and you want to be the ebb of this great flood and would even rather go back to animals than overcome humans? What is the ape to a human? A laughing stock or a painful embarrassment. And that is precisely what the human shall be to the overman: a laughing stock or a painful embarrassment. ${ }^{5}$

Nietzsche also compares the necessary enhancement of the human spirit to a triadic metamorphosis of animals: from the camel obeying the dragon of tradition, to the lion battling this dragon, to the newborn child. ${ }^{6}$ As partly pointed out by Philip Koberski, this whole metamorphosis may be clearly detected in 2001's imagery. ${ }^{7}$ The disciplined inhabitants of the spaceships and moon colonies-from visitors, to stewardesses, to astronautsact as the Nietzschean camels, blindly obeying the dragon of tradition, with its command, "Thou shalt." The supercomputer HAL 9000, whose mind is one with its automated machinery, emerges as the over-dragon, who is killed by the camel-turnedlion, David Bowman. However, since the lion has only freed itself from old values but developed no new ones, the dying Bowman metamorphoses into the foetus hovering in space above the Earth, after passing through the monolith, which now functions as a cosmic gate. This appears as a radicalisation of the Nietzschean child signalling "innocence and forgetting, a new beginning, a game, a wheel rolling out of itself, a first movement, a sacred yessaying." 8 As in a premonition of Kubrick's The Shining (1980), the rejuvenated Bowman is no longer a "dull boy," all work and no play.

The ability of the film's central catalyst, the alien black monolith, to cause leaps forward in man's evolutionary destinygreat floods instead of an ebb-is implied by a spectacular temporal symbolism. When the monolith turns up the first two 
times-in the rocky hollow among the African humanoids, and excavated on the moon-we discern an accelerated movement of time (Fig. 1). Although the dispersed sunlight—first cast on fragile, shadowy clouds, and then on the fringes of the otherwise dark lunar excavation site-clearly indicates a sunrise, the sun actually is revealed at its midday zenith, right over the dark monolith. This paradoxical time mix (seemingly hitherto unobserved) seems again to be a concretisation of Nietzschean imagery, for, as Zarathustra declares in his very last words in the novel, "'This is my morning, my day is beginning: up now, up, you great noon!'-Thus spoke Zarathustra and he left his cave, glowing and strong, like a morning sun that emerges from dark mountains.” [Nietzsche's italics] ${ }^{9}$

To use a later transhumanist term, Kubrick's view of evolutionary progress that accelerates sunrise into noon could be described as extropian, that is, as increasingly anti-entropic and dominated by a Cartesian intelligence that is ultimately detachable from the fragile human body.10 In Kubrick's words, "truly advanced beings would probably have shed the chrysalis of a biological form at one stage of their evolution."11 Here, Kubrick and his manuscript co-author, Arthur C. Clarke, seem to be in accord with the space scientist Frederick Ordway, their technical adviser on questions of extra-terrestrial intelligence. In Intelligence in the Universe (1966), which Ordway wrote with Roger A. MacGowan, a computer scientist at the Army Missile Command in Huntsville, he emphasises how machinic intelligence will universally outdistance organic life, as biological evolution will be increasingly controlled, to "a degree which does not exist today, even in dictatorships.” In this mechanised future, in which emotions and irrationality play almost no role, except as a hindrance to progress, the durability and more efficient modularity of computers will do away with alleged animal weaknesses such as illness, death, slow learning and lack of the possibility to improve an IQ. ${ }^{12}$

Faced with the emphasis on machines as the future masters of the universe, Kubrick's choice of a black monolith as representative of extra-terrestrial intelligence in 2001 does not seem to be only a question of abstract symbolism, to avoid the danger of, in Kubrick's own words, "the traditional bug-eyed monster of pulp science fiction." 13 The media Kubrick imagines will take over the warm, fragile bodies of organisms resemble, in a surprisingly concrete way, the black monolith and its hard geological or otherwise inorganic surroundings in outer space: “... 

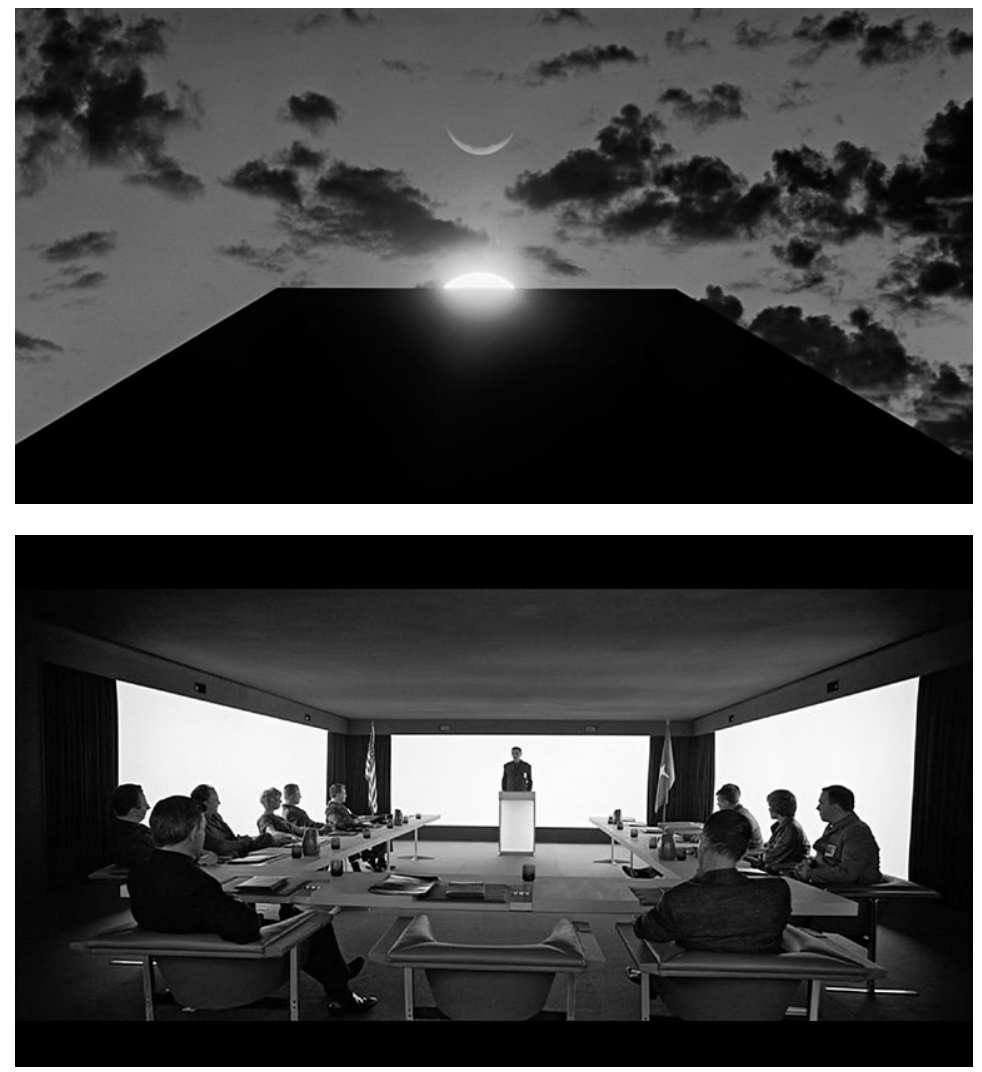

Fig. 1

Monolith with simultaneous sunrise and zenith. Still from 2001: A Space Odyssey (1968).

Fig. 2

Heywood Floyd speaks before the crew at the Clavius moon base. Still from 2001: A Space Odyssey (1968). 
I suppose that intelligent rocks or crystals, or statues, with a silicon life base, are not really impossible, or even conscious gaseous matter or swarms of sentient electrical particles." 14 According to Carl Gustav Jung's interpretation of the post-war phenomenon of flying saucers-one that oscillates ambivalently between outer space and the collective unconscious-a "sentient electrical field" is also what "speculative ufologists" imagine as a possible seat of alien intelligence; and Kubrick joined this speculative crowdprobably inspired by Jung, as we will see. ${ }^{15}$ Yet, simultaneously with its pointing outwards to alien intelligences, the monolith also points inwards to human technology. Here, its black geometry seems little more than shorthand for those machinic encasings that are already in the process of converting the astronauts to a state of purified rational intelligence, based in inorganic, posthuman media that reach beyond the organism. This is confirmed by the monolith's rectangular form being echoed in many instances in the artificial surroundings, notably as frame for the red eye of HAL 9000, the already incorporeal intelligence.

However, the black monolith not only signifies pure, rational intelligence, but also creativity-to the point of becoming a meta-commentary on the film itself as a trigger of evolutionary becoming. As has been observed with increasing frequency on the Internet in recent decades, ${ }^{\mathbf{1 6}}$ the rectangular format of the monolith is identical with the frame of the cinematic screen, a link emphasised in the prelude to 2001, in which the cinema screen is shrouded in monolithic darkness for several minutes, while the soundtrack plays György Ligeti's Atmosphères (1961). This signals a mise-en-abyme in which the very images of the film emerge as a result of the monolith's spark of creativity, the monolith simultaneously a product of the film it generates. In this way, Kubrick emphasises that human creativity, with its zenith in his own cinematic genius, is at the point of becoming part of the cosmic evolutionary genesis. In transforming themselves into Nietzschean overmen, human beings assume the role of God, or rather, become his naturalized followers in the form of the supreme cosmic intelligence with which they communicate.

In the foregoing perspective, the monolith becomes a rather ambiguous figure, pointing not only towards a more or less incorporeal intelligence, but equally towards an embrace of rationality's suppressed counterpart, nature's subconscious drives. This ultimate reconciliation of intelligence and matter, the paleofuturist circle's conjoining of deep future and deep past, is consistent with the similar paradoxical fusion of opposites that 
Zarathustra strives for in Nietzsche's novel: joy and pain, love and hate, blessing and curse, noon and midnight, what Nietzsche sums up to the world.17 In 2001 this striving for worldly synthesis is negatively hinted at in the scene where Heywood Floyd gives his moralistic speech to Clavius's crew, claiming that the people of Earth would experience a cultural shock if they were to hear of the alien monolith, and that therefore it should be kept a secret. Surrounding this scene of anthropocentric bigotry are what may be seen as the purely rationalistic anti-poles to the black monolith, three cinematic screens glowing with an empty white light (Fig. 2).18

Throughout the film one observes that the spark of creation, the ability to conceive, moves from a purely male to a more complex female or androgynous sphere, from intelligence to womb-brain, from spirit to what in new materialist terms might be called "vibrant matter." 19 One need not have an overly feminist sensibility to note that there are very few women in the cold, extra-terrestrial, and male-dominated surroundings of 2001, all playing insignificant roles, or visually displaced-for instance, Floyd's wife and his daughter's babysitter, during the space station videophone call to earth. However, this does not mean that 2001 conveys suppressed sexuality, heterosexual or otherwise. Sexuality is instead displaced to the inorganic agents: to the machines, the celestial bodies, the rocks on the moon and in Africa, and space itself-all agents displaying a cool promiscuity. Not for nothing did Kubrick say to the New York Times in 1968: "There is a sexiness to beautiful machines. ... We are almost in a sort of biological machine society already."20

Indeed, the whole sequence from Floyd's trip to the reborn foetus in outer space could be seen as a tortured procreation, unfolding across separate temporal stages. ${ }^{21}$ After the longitudinal, white Pan Am flight has penetrated the vaginal red opening of the rotating space station, a white sperm cell, the rounded moon shuttle, is sent off to penetrate the similarly red sub-surface of the egg-moon, thus participating in the moon impregnation already performed by the buried monolith. Accordingly, the Discovery One spaceship introduced eighteen months (two human pregnancies) later manifests the womb for this double impregnation of the moon. Yet the spaceship's sperm-like, spherical head and tail of nuclear energy units also represents a rational male extension of physical impulses. In fact, this extension is so dominant and immature that the male-female coupling develops into conflict. This unstable womb-brain ends up aborting its own off-spring, the three hibernating astronauts 
in their metallic cocoons and Frank Poole, whose oxygen tube, the artificial umbilical cord, is broken by HAL, its uncaring male mother. Only after disconnecting HAL's intelligence, an act that also takes place in a red, womb-like room, is Bowman ready to enter the Star Gate, a vaginal passage leading him, inside his spermatozoan pod, to the primordial depths of a truer cosmic womb. Through a sort of reversed evolution, an infantile regression-from geometric patterns (rational urban civilisation), to inner-corporeal biological/cosmic ones (organic body), to archaic rocky and watery landscapes (vibrant inorganic matter)he ends up in what could be understood as a more functional alliance between brain and womb, in a white, Louis XV rococo interior that the extra-terrestrial intelligence has generated from his imagination, and which finally produces his Nietzschean rejuvenation, the cosmic foetus floating in space without any trace of technology, rationalism's offspring.

As indicated by John Izod and Philip Kuberski, and given a broader basis by Julian Rice, the key idea of the desire to reunite with consciousness' big Other has not only Nietzschean origins, but derives from what amounts to Kubrick's ongoing exploration of Carl Gustav Jung's ideas. ${ }^{22}$ As Kuberski remarks, "2001 comes close to being an explicitly successful individuation, a reconciliation and integration of the ego with its shadowy double, the cosmos itself." 23 When Kubrick told an interviewer in 1970 that "The God concept is at the heart of the film," he was referring to Jung's specific idea of God as the reconciliation of the individual mind with its normally excluded other: the shadow and its extension into the collective unconscious that manifests itself in myths and dreams. ${ }^{24}$ Jung explains:

Although the God-concept is a spiritual principle par excellence, the collective metaphysical need nevertheless insists that it is at the same time a conception of the First Cause, from which proceed all those instinctual forces that are opposed to the spiritual principle. God would thus be not only the essence of spiritual light, appearing as the latest flower on the tree of evolution, ... but also the darkest, nethermost cause of Nature's blackest deeps. ${ }^{25}$

"Nature's blackest deeps," the collective base of the individual's shadow, relates directly to 2001, to the cosmic darkness with which its latest evolutionary superstructure, purified rationalism, may reunite in a coincidentia oppositorum. This also corresponds 
to Zarathustra's monistic world synthesis, dissolving all dualisms, and his demand to remain faithful to the earth. ${ }^{26}$ The monolith appears as a solidification of this all-embracing darkness, and Kubrick indeed refers to it as "in itself something of a Jungian archetype.”27 In particular, the idea of extra-terrestrial intelligence as a modern manifestation of numinosity, a contingent mythic imprint of the collective unconscious, appears to be inspired by Jung, whose speculations on a meeting with extra-terrestrials are referred to by Kubrick. ${ }^{28}$ In his analyses of UFOs, Jung does not reject their physical reality, but emphasises that in any case, UFOs appear as a collective phantasm, a desire for "intervention by extra-terrestrial 'heavenly' powers,” provoked by Cold War anxieties of nuclear apocalypse and overpopulation. ${ }^{29}$ Jung also alludes to the UFOs in terms of the uterus and phallic penetration that are close to the technological and cosmic sexuality of 2001. And his observation that anchorites are especially receptive to "numinous fantasy images, visions and hallucinations" reminds us of the celibate Dave as he is prepared for the hallucinatory journey to the cosmic womb-brain, a metaphysical version of the similarly mind-transgressing psychedelic trip so typical of $1960 \mathrm{~s}$ drug culture. ${ }^{30}$ Moreover, Jung's preoccupation with alchemy as pre-modern bridge-building between matter and spirit probably inspired the alchemical symbolism of this journey: the monolith as the philosophers' stone that first reduces Dave to a re-purified prima materia (the regression through the Star Gate to the cosmic womb), then catalyses his rebirth as gold, or the superman (the passage from the death-bed to cosmic foetus). ${ }^{31}$

The idea that Dave, in his journey, is approaching the big Other of separate consciousness could be confirmed by consulting Jung's analysis of The Black Cloud (1957), one of the many science fiction novels by noted astronomer, Fred Hoyle. ${ }^{32}$ The saucer-shaped cloud of extra-terrestrial intelligence that disturbs the orbits of Saturn and Jupiter, and is expected to reach the Earth in eighteen months (cp. the length of Discovery's journey), is seen as such a powerful manifestation of the collective unconscious, utterly uncontainable by consciousness, that its earthly communicators fall into delirious states followed by death. Elsewhere, Jung remarks that if the unconscious is exposed like that, collective dream images link to cosmic qualities,

such as temporal or spatial infinity, enormous speed and extension of movement, 'astrological' associations, telluric, lunar, and solar analogies, changes in the proportions of the 
body, etc. ... The collective element is very often announced by peculiar symptoms, as for example by dreams where the dreamer is flying through space like a comet, or feels ... that he is dead, is in a strange place, is a stranger to himself, confused, mad, etc. ${ }^{33}$

Apart from these Jungian passages, several scenes in 2001 seem to specifically draw on a series of delirious visions Jung himself described, provoked by a near-death experience in 1944 . As recounted in Jung's widely read memoirs, dictated in 1957 to Aniela Jaffé, and which he edited himself:

It seemed to me that I was high up in space. Far below I saw the globe of the earth, bathed in a gloriously blue light. ... Something new entered my field of vision. A short distance away I saw in space a tremendously dark block of stone, like a meteorite. It was about the size of my house, or even bigger. It was floating in space, and I myself was floating in space. ${ }^{34}$

This passage has obviously inspired Kubrick's images of the spaceships and space station floating above a gloriously blue earth. Kubrick remarked that the vast oceanic stretches of Homer's Odyssey evoked the same mystery and remoteness as space does today, but in this moment of 2001, these stretches appear in their tamest version, congruent with the elegant, highbourgeois comfort of Johann Strauss the Younger's Blue Danube waltz (1866). ${ }^{35}$ On the other hand, the monolith as "something of a Jungian archetype" is concretely matched by Jung's vision of a "tremendously dark block of stone," when Bowman encounters the free-floating monolith in the more mysterious and remote depths of space, above Jupiter. Like the monolith, Jung's dark stone turns out to be a liminal gateway, containing a kind of Hindu temple that leads beyond death, which Jung escapes only when called back to Earth by his doctor, who appears as an archetypical image of sorts. Approaching but not entering the temple, Jung "had the certainty that I was about to enter an illuminated room," where he would meet the people he had known, and finally understand "what historical nexus I and my life fitted into."36 Later, summing up his experience of this and other visions, he describes it as close to "eternal,"

the ecstasy of a non-temporal state in which present, past, and future are one. Everything that happens in time had 
been brought together into a concrete whole. Nothing was distributed over time, nothing could be measured by temporal concepts.

... The only thing that feeling could grasp would be a sum, an iridescent whole, containing all at once expectation of a beginning, surprise at what is now happening, and satisfaction or disappointment with the result of what has happened. ${ }^{37}$

It seems plausible that the collapse of time into an "iridescent whole,” or “illuminated room,” telescoping Jung's life into an eternity, is transformed into the glowingly white, rococo rooms into which Bowman, in his pod, is catapulted through the Star Gate, then being variously surprised, satisfied and disappointed when he sees himself, as from without, passing through various life stages. As his individual consciousness merges with its former surroundings, spatial positions also seem unstable, the pod, table and bed flickering about in the interiors. Jung specifies that the time-blending experience "might best be defined as a state of feeling, but one which cannot be produced by imagination.”38 Jung contrasts this ecstatic experience with his former life, which now appears as a drab, grey and empty illusion, a prison, or a system of boxes: "For it seemed to me as if behind the horizon of the cosmos a three-dimensional world had been artificially built up, in which each person sat by himself in a little box."39 Jung's prisoning, rationalist system of boxes, the pale reflection of the real cosmos, seems to hover behind both the architectural grids of outer space vehicles and 2001's rococo rooms. Although the rococo rooms condense Bowman's life into an eternity, in Kubrick's words, "a timeless state," they are nevertheless "drawn out of his own dreams and imagination" by the extra-terrestrial intelligence, as a "human zoo approximating a hospital terrestrial environment." 40 More precisely, they summarise Enlightenment rationality, the floors divided by the same glowing white grids that are seen in the Hilton space station, for instance. All this is left behind only when Bowman is reborn as a Nietzschean foetus, finally reconciled with the blackest deeps of the cosmos, and leaves technology behind. These triumphant images of the foetus in the embrace of dark space itself clearly echo another of Jung's visions, where again, he felt he was floating in outer space, "as though I were safe in the womb of the universe-in a tremendous void, but filled with the highest possible feeling of happiness.”41 
What Kubrick does with Jung's liminal experiences is to translate them from the realm of human individuation and probing of the collective unconscious into the realm of posthuman evolutionary promise. Only by realising the passage beyond death, by passing through the monolith and being reborn as a Nietzschean star child does Bowman manage to integrate his ego with its shadow. The very idea of a foetus in a free-floating, semi-transparent membrane, among other celestial bodies, was probably inspired by a vignette in one of Kubrick's sources for the evolutionary origins of man, Robert Ardrey's African Genesis (1961) (Fig. 3/4). Here, in a sort of cosmic dream illustrating the baby's primordial "Illusion of Central Position," a baby is embedded in a crystallike bubble, hovering among other bubbles. ${ }^{42}$ Also, Jung's UFO book may again have provided inspiration. When analysing John Wyndham's sci-fi novel, The Midwich Cuckoos (1957), in which an extra-terrestrial "thing" causes the birth of children with golden eyes and extraordinary intelligence, Jung speaks of a "divine intervention that gives evolution a definite push forward."43

\section{INHUMAN AUTOMATISMS: WEAK AND STRONG}

The final rebirth in 2001 shows paleofuturism coming full circle, the deep past (matter) being reached by pursuing the deep future (intelligence). However, throughout 2001-and more broadly, all Kubrick's films-humans seem trapped between the incomplete and ambiguous appearances of the domains of the pre-conscious and the post-conscious. Even in their "human" lives, Kubrick's figures are typically marked by an uncomfortably inhuman quality, infiltrated by forces they do not control: sexual or aggressive drives, or alienating system rules that may be military, work-related, or mechanical. ${ }^{44}$ Corresponding to Jean-François Lyotard's later notion of the inhuman, these automatisms, whether instinctual or mechanical, are located at the outer fringes of an evolutionary coming-into-being, either in the prehuman domain, a core of uncurbed animal instincts always inhabitingand paradoxically, defining-the human, or in what we could broadly term the posthuman domain, civilisation's sets of rules that constantly threaten to violate humans' recently acquired autonomy, turning them into automatons. ${ }^{45}$

In A Clockwork Orange (1971), the title itself merging the mechanical and the organic, the young thug, Alex, has become a prisoner of his prehuman, animal instincts, an instrument for engaging in sexual ultra-violence for pleasure, in an existence otherwise paralysed by civilisational boredom. However, 

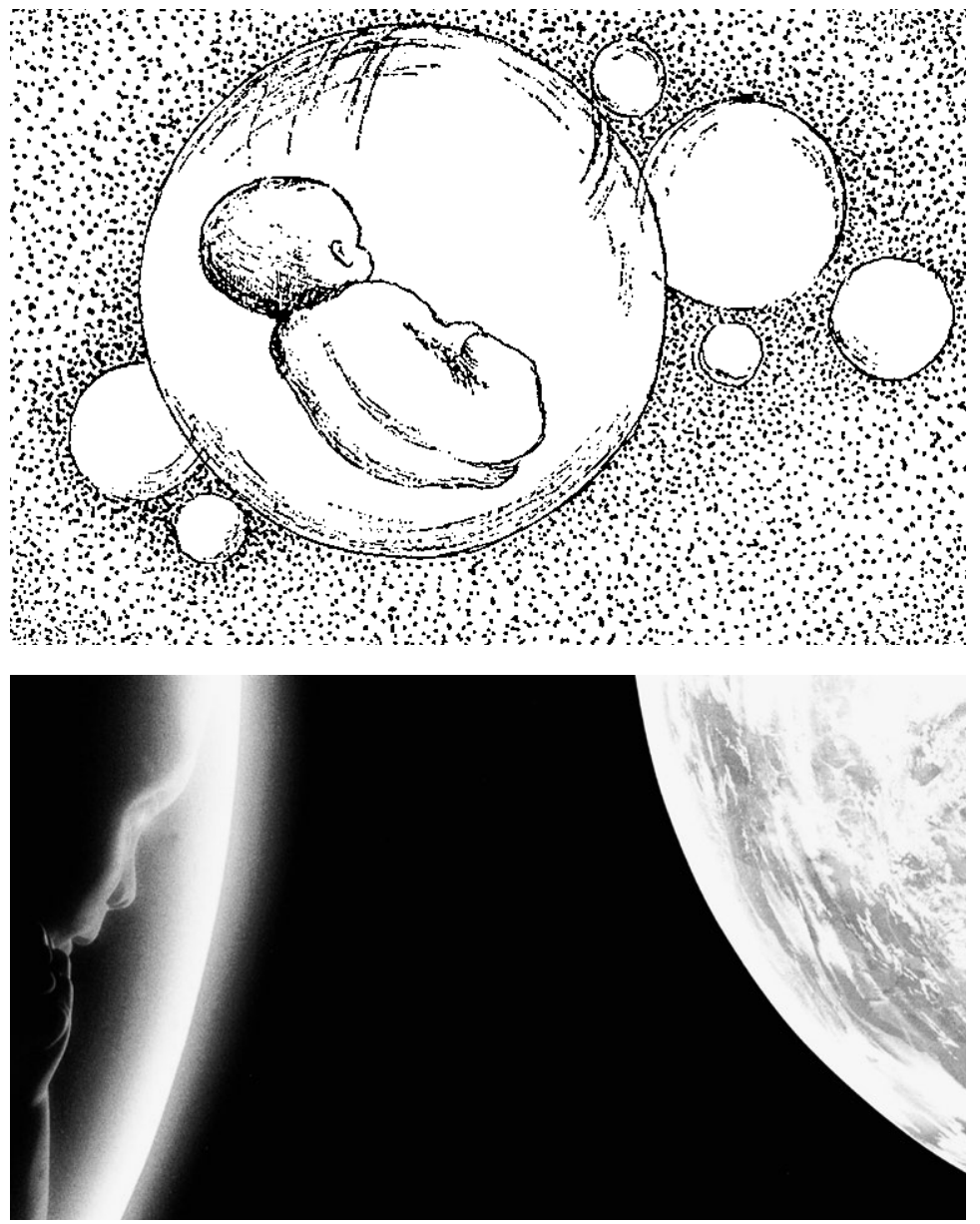

Fig. 3

The baby's primordial "Illusion of Central Position."

From Robert Ardrey, African Genesis: A Personal Investigation into the Animal Origins and Nature of Man (London: Collins, 1961), 143.

Fig. 4

The star child hovering in space above Earth.

Still from 2001: A Space Odyssey (1968). 

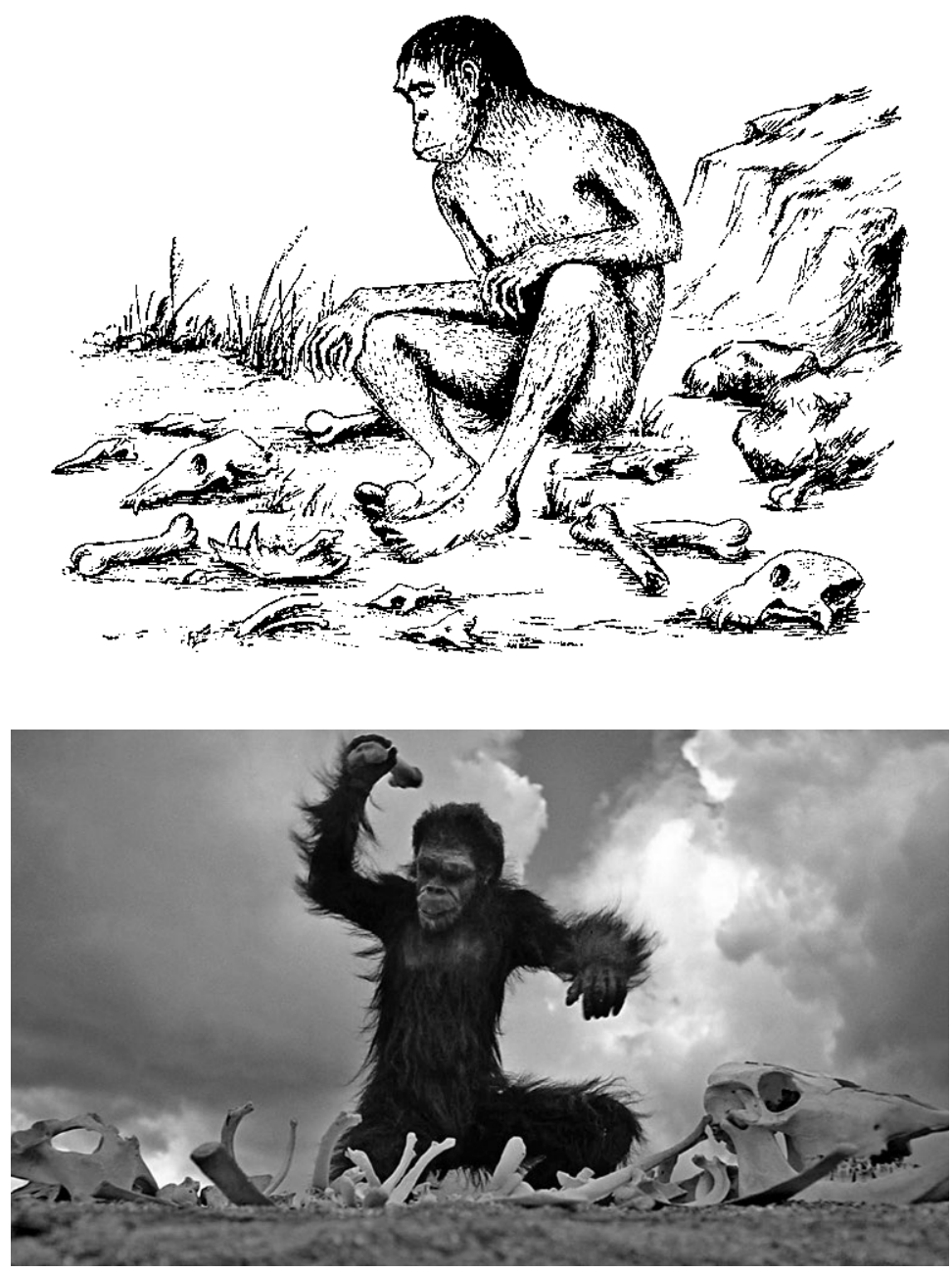

Fig. 5

Australopithecus ape among bones. From Robert Ardrey, African Genesis: A Personal Investigation into the Animal Origins and Nature of Man

(London: Collins, 1961), 175.

Fig. 6

Ape in ecstasy of bone destruction. Still from 2001: A Space Odyssey (1968). 
such instincts actually seem crucial to his normal-humanfunctioning, which becomes clear when his aggression and sexual addiction are artificially suppressed by the Ludovico cure, and he turns into a dysfunctional wreck. Similarly, in The Shining, the writer Jack Torrance becomes a programmable killing machine for the evil forces of the Overlook Hotel after he has internalised and subverted the Protestant work ethos, by maniacally repeating the sentence, "All work and no play makes Jack a dull boy."

War logically constitutes a central theme in Kubrick's work, since it completely blurs the boundaries between instinctual animal aggression and that over-regulated machine that turns humans into automated puppets of mechanical forces outside themselves. For instance, in Paths of Glory (1957), Colonel Dax (Kirk Douglas) fights in vain to save his men from execution, after they have been unjustly accused of cowardice in an ill-planned attack forced by far-away authorities. And in Dr. Strangelove (1964), the fight is against a whole row of interconnected, automated systems: the mad general Ripper who isolates himself, the blocked swarm of B-52 bombers, and the automatic Russian doomsday machine.

In 2001, too, the cognitive leap forward that implants in the minds of the humanoids the capacity to use tools is one that ignites an instinct for violence and killing. Here, Kubrick and Clarke responded to Robert Ardrey's then-recent hypothesis that the precursors of Australopithecus survived millions of years of drought, as the savannah spread at the expense of forests, by adopting the hunting habits of carnivorous species. ${ }^{46}$ Indeed, Kubrick's morbid localisation of the eureka moment-an alpha male beginning to play with the bones of a scattered animal skeleton-is clearly inspired by "A Roomful of Bones," Ardrey's detailed description of Raymond Dart's finds in South African Makapan, beginning in 1947 (Fig. 5/6). From this pile of animal debris, complete with wound traces, we learn that the first human weapon, a double-headed instrument, appears to have been the humerus of an antelope. Thus, the alpha male's ecstasy of bone destruction in 2001 constitutes the yet-living overlay of Ardrey's "fossil memento of violence," including an antelope bone that was apparently thrust into a hyena's mouth and damaged its skull. ${ }^{47}$ Here, the mythical material that Kubrick evokes with respect to recent paleoarcheology is the biblical tale of the Fall. The African savannah, with its dry leaves as its fruits, is a demonstratively harsh Edenic garden; the monolith is a hard Tree of Knowledge; the homicidal alpha male is Cain. In this modernised version 
of paradise, God seems, Nietzsche-fashion, to be long dead, or perhaps displaced to other parts of the universe and to humanity's future. By being mentally fertilised by the monolith, itself implanted by an extra-terrestrial, quasi-divine intelligence, the humanoids now have the possibility of becoming divine, the ethical dilemma being that the path to divinity goes through the valley of death.

Over a vignette of a revolver-which sets the scene for Kubrick's match cut from bone to satellite-Ardrey concludes "that the continuity of development in man's cultural efforts is not truly that of the tool; it is that of the weapon."48 Following Dr. Strangelove's ending, with an all-devastating nuclear apocalypse-a response to the Cold War arms race, and specifically to the Cuban Missile Crisis of 1962-the originally planned opening to part II of 2001 was to have revealed a whole battery of nuclear bombs-Russian, American, French, German, Chinese-hovering 200 miles above the Earth. ${ }^{49}$ In Arthur C. Clarke's novel, developed independently of the film's manuscript, the star-child very pedagogically makes his first deed the destruction of these nuclear arsenals. This messianic miracle marks his status as "master of the world," and thus turns Ardrey's baby in the "Illusion of Central Position" into reality. ${ }^{50}$ However, in the finished film, Kubrick chose to tone down these explicit martial allusions, and to limit the Cold War references to the tensions between Heywood Floyd and the group of Russian scientists. ${ }^{51}$ Still, Kubrick's identification of the starchild as representing the "next leap forward in man's evolutionary destiny" is surprisingly tainted with shadows of contemporary politics. Neil Armstrong's soon to occur "big leap for mankind" was declared only with a first moon landing, which was realised after an aggressive moon race with the Russians-itself a thinly disguised development of the Cold War arms race. Even darker undertones are evoked by Mao's “Great Leap Forward” of 195861, another expression of impatience with the pace of cultural evolution, which killed millions of Chinese citizens.

Only in A Clockwork Orange do we meet the descendants of 2001's club-bearing apes unfiltered: Alex's sadistic gang with their truncheons. In 2001 the indeterminacy of the bone-turnedsatellite emphasises that the apes' descendants have become at least outwardly civilised, and have seemingly done away with all aggression, probably as a result of adapting to, or at least coevolving with, the new technological environment of spaceships and moon colonies. These hyper-artificial surroundings appear as the apotheosis of the ideals of modernist functionalism, 
gleaming with white polished metal, glass, and plastic, and mostly shunning colour, except for diverse monochrome upholstery on chairs and panels, and projected colours of light, notably red, coming from the myriads of screens, buttons, and light panels. These are literal examples of machines à habiter, the ideal dwelling of the high priest of functionalism, Le Corbusier, concretely incorporating his desire for the imitation of modern transport vehicles, notably ships. Humans functioning in these surroundings seem to have lost all their animal impulses, and are now themselves controlled, polished and soft-spoken, never laughing, crying, or becoming upset, let alone being sexually aroused. They incarnate Le Corbusier's characterisation of modern man as "intelligent, cold and calm." This man has "the mechanical sense. ... This feeling for machinery is one of respect, gratefulness and appreciation." 52 Here, the humanoids' testosterone-driven aggression seems to have been sublimated into another form of masculinity, a rational, brain-dominated behaviour in harmony with the machines they operate and communicate with, the artificial intelligence of HAL 9000 being the example par excellence.

The automatised male universe is a supreme example of Kubrick's tyranny of systems, a Lyotardian, inhuman structure, in which humans lose their autonomy and become puppets of forces not their own. ${ }^{53}$ This may indeed appear as the outcome of several critiques of modern rationalism, from Nietzsche's dragon of duty and Jung's restrictive three-dimensional box system, mentioned earlier, to Max Weber's "steel-hard box" of de-enchanted rationality, Lukacs' and Adorno's consciousnessdominated "second nature," even more life-threatening than the first one against which it should protect, and Heidegger's "Enframing” (Ge-Stell), an all-encompassing grid-structure that turns nature, including human beings, into "Standing Reserve" (Bestand) for technology's unstoppable needs. ${ }^{54}$

In Kubrick's new universe, martial aggression has therefore not evaporated. Like sex, it has merely been displaced to the machinery that ultimately has become a potential enemy of humans. This is revealed when HAL 9000, upon being threatened with disconnection, kills Poole and the hibernating astronauts. Since the technological dangers of HAL add up to Nietzsche's dragon from Also sprach Zarathustra, the over-systematised tradition of duty, it must be fought-which happens when Bowman metamorphoses from serving "camel” into rebellious "lion.” However, considering that the monolith indicates a future 
in which machines have replaced organic bodies as seat of the most advanced sort of cognition, HAL's murderous action is also premonitory of this imminent evolutionary take-over. As posited by Kubrick, then, the dilemma of humans vs. machines is highly complex, and resembles Heidegger's dilemma of Enframing. Although Enframing presents the utmost danger, Heidegger also notes, with introductory lines from Hölderlin's hymn Patmos, "But where danger is, grows/The saving power also." For, "The saving power is not secondary to the danger. The self-same danger is, when it is as the danger, the saving power."55

How technology's dangers could become the power that saves in 2001 remains hypothetical, but it might include recognition of HAL's agency in its own right, and ending the hypocritical secrecy about the discovery of the monolith, HAL's ally in artificial intelligence. Clarke specifies in his novel that the problem of both sustaining a rational ideal of transparency and guarding the Jupiter mission's secret is what triggers HAL's madness; in the film, the madness is specifically triggered when Bowman, upon being asked by HAL about the strange secrecy of the mission, in a strict and heartless tone orders HAL to return the crew's psychology report. 56 Thus, paradoxically, the computer ends up being much more emotionally driven than the humans, who seem coldly isolated from each other, and are only able to approach more intimate relations via remote media (Heywood Floyd and his daughter; Poole and his parents on his birthday party).

In any case, with an ambivalence resembling Heidegger's coupling of danger and saving power, in 2001 both the dangers and their utopian resolution seem to reside in the inhuman domain. In what we could term the weaker inhuman force field, one that still promotes a masculine ego, humans are stuck between a first-step pre-human (the aggressive ego-promoting impulses of the apes), and a first-step posthuman (the sublimation of these impulses into a domain of pure cognition: the imprisonment in over-rational rules and their mechanisation through machines). Yet in order to enter a truly posthuman level, one that may, in a paleofuturist move, connect radical posthuman with radical prehuman, humans should link to the less organised and, from a still-dualist viewpoint, feminine matter lying beneath individually separated bodies. In Jungian terms, this is what leads from the individual's shadow to the cosmic womb. 
With its paleofuturist move 2001 is intervening in a broader cultural terrain, a complex intermingling of science fiction, astrobiological speculation, popular science, pseudo-science, New Age religion, Cold War desires for alien visits, and visual art movements such as minimalism and earth art. According to all these trends, somehow, the hard, inorganic materiality of the future was already present in the deep past, be it in archaic monuments or distant geological epochs. In 2001 and the scientific cultures it draws on (serious, popular, fictitious) the link is extra-terrestrial intelligence, a topic whose representations across media and disciplines I will now examine.

As a sign of the close entanglement of serious speculative science and science fiction, we find that several of the key themes of 2001 recur in contemporary scientific overviews of the possibility of extra-terrestrial intelligence, notably the two presented in 1966 that Kubrick himself considered best: Ordway and MacGowan's, and I.S. Shklovskii (a Soviet astronomer Kubrick refers to in an interview) and Carl Sagan's (the renowned astrobiologist and popular science writer). ${ }^{57}$ For example, Ordway (Kubrick's and Clarke's own consultant) and MacGowan speculate that,

an extrasolar expedition might have visited Earth during the early development of Australopithecus, Homo habilis, or Homo Erectus and taught small colonies techniques they would not have discovered themselves for tens or hundreds of thousands of years. 58

Such a visit could have left traces in the form of space probes, instruments, a being "(if organic, in fossilized form)," or indeed, as in 2001, what we call art: "a monument"59 or, to adopt Sagan's words, "an object of incredible beauty or devastating power that we were unable to either understand or reproduce." 60 It could also have left traces elsewhere in the solar system, for instance, on a moon of Jupiter, or our own moon. Due to cosmic infall, remains here would be buried perhaps "a few feet or yards" beneath the soil.61 And as Drake and Clarke suggested, an alarm-later echoed in Kubrick's formulation, "a kind of cosmic burglar alarm"-could sound across interstellar space when the local technological level had reached a certain point.62 
Strikingly, the foregoing scientific speculations had genealogies in a repertoire of wild fantasy and pseudo-science that Kubrick was familiar with from news-stands in the Bronx in the 1930s.63 In pulp magazines such as Amazing Stories and Weird Tales, which introduced the idea of paleocontact, the so-called "ancient astronaut thesis,” H.P. Lovecraft-like Nietzsche and Jungsuggested that our human consciousness-dominated world is but a figment of a far greater, both terrifying and exuberant, cosmic reality. Its subdued presence is detected in artefactual ruins of deep geological strata, as though technology and art were part of a primordial subterranean creativity. In "The Call of Cthulhu" (1928) cyclopean stone remains in the Pacific, including "monoliths and sepulchres" bear witness to the first rulers of the Earth, gods from outer space, including the submarine monster, Cthulhu. These creatures from the stars, the Great Old Ones, "brought Their images with Them," and could be revived from their present deathlike sleep when "the stars had come round again to the right positions in the cycle of eternity." 64 And in "At the Mountains of Madness" (1931) bas-reliefs in a ruined Antarctic city depict how terrestrial life, including mankind's simian predecessors, were created by these alien visitors (partly for food, partly for amusement) ${ }^{65}$

At a structural level, 2001 recirculates large parts of Lovecraftian mythology (god-like intelligences governing a primordial earth, and leaving awe-inspiring, partly subterranean monuments; their creation/education of simian ancestors; re-encounters with these intelligences at the right stellar configuration). Yet with its minimalist cinematic language and hermeneutic openness, 2001 suggests a version of the ancient astronaut thesis that manages to not offend the "serious" scientific sensibility. With its indistinct explanatory framework for the mysterious, meteorite-like object that lands on Earth, Lovecraft's "The Colour Out of Space” (1927) specifically helps Kubrick to avoid the stereotypical "B.E.M.," the "bug-eyed monster of pulp science fiction." Like the monolith in 2001, the object is inert, with a glossy texture and unfathomable colour that can be described only through analogy:

It was just a colour out of space-a frightful messenger from unformed realms of infinity beyond all Nature as we know it; from realms whose mere existence stuns the brain and numbs us with the black extra-cosmic gulfs it throws open before our frenzied eyes. ${ }^{66}$ 
Here again, we are close to 2001's regions "beyond the Infinite," complete with "frenzied eyes."

Recycled and elaborated on by other writers in American pulp magazines of the 1940s and 1950s, in the 1960s Lovecraft's extraterrestrial fantasies converged with a wave of "real" and pseudoscientific speculation, the whole a confusing blend of science and sensationalism, Cold War paranoia and New Age religious hopes. Integrating Soviet theories, including an exploded atomic spaceship over Tungus, and French speculation on extraterrestrial archaeology (Louis Pauwels, Jacques Bergier, Robert Charroux), the craze acquired viral, global momentum with the Swiss hotelier and charlatan, Erich von Däniken, starting with his paleofuturist title, Erinnerungen an die Zukunft (1968). ${ }^{67}$ All sorts of ancient monuments now became "evidence" of extra-terrestrial presence: astronauts parading as gods in Pre-Columbian reliefs, Egyptian pyramids as evidence of sovereign alien engineering technology, the large desert figures on the Peruvian Nazca plain being intended for viewing from alien aircrafts, and so on. Including subterranean Indonesian cosmonaut reliefs, re-encounters with a flying saucer, alien telepathy, and psychedelic hypnosis, Hergé's late Tintin album, Vol 714 pour Sydney (1968), comprises a notable cartoon digest of these ideas of paleocontact. ${ }^{68}$ Despite-or rather, because of-the close similarities between von Däniken's reasoning and his own, in the mid-1970s Carl Sagan had to distance himself from the Swiss pseudo-archaeologist's mistakes, including his "pop religion," the "very dangerous doctrine" that "beings from elsewhere will save us from ourselves.”69 Sagan's self-protective criticism is close to Susan Sontag's contemporary accusation that 2001 integrates certain formal aspects of fascist aesthetics, those centring "on the orgiastic transactions between mighty forces and their puppets." 70

If Lovecraft contributed to shaping 2001's monolith into a marvellous opacity, this happened through a series of developments of Arthur C. Clarke's short story "The Sentinel” (1950). ${ }^{71}$ Its mysterious, glittering pyramid, first introduced as a remote glimpse in a rugged blue-white moon landscape, shifted in 1965 from black tetrahedron, to transparent cube, finally, to the black rectangular slab. ${ }^{72}$ In Clarke's short story, the advanced extra-terrestrial civilisation that left a cosmic "fire-alarm" would soon return (with worryingly unknown intentions), now that the young civilisation had passed its first test, escaping earth and avoiding nuclear self-destruction. Ironically, the pyramid's secret is penetrated only after it is blown to pieces by an atomic weapon. 
The ascent to its location, an artificial rocky plateau, recalls the pitfalls of Nietzsche's Zarathustra: if a climber falls down (and does not break his neck), he will become the "laughing-stock of the expedition," reminding us of the Nietzschean relationships of ape/man and man/overman, including the dangerous rope crossing that links the latter dualism, from which the tightrope walker actually falls and dies. ${ }^{73}$

The skeletons in the closet of evolutionary progress are heavily pronounced in another, largely unnoticed source for 2001, Nigel Kneale's BBC TV series, Quatermass and the Pit (broadcast 195859). ${ }^{74}$ Confirming the adage (sometimes attributed to Picasso) that good artists copy, great artists steal, its surprising range of 2001 raw ingredients has been overlooked, probably because they are so explicitly presented, in contrast to Kubrick's semantically open and multi-layered visual language. During an urban excavation with digging machines (to extend the London Underground by Knightsbridge) fossil remains of ape-men, soon followed by a five-million-year-old artefact, are discovered among the piles of earth. The pit, complete with ramp, metal sheets, and strong spotlights around the mysterious object, is clearly the model for Kubrick's moon excavation (Fig. 7/8). At first, it is feared that this object is a bomb (echoing the bone-weapons' mutation to nuclear missiles in the earlier version of 2001), but later it turns out to be the wrecked spaceship of visiting Martians, their insectlike, dried-out bodies discovered in the spherical cockpit. Again echoing 2001, these humanoids have been surgically modified to improve their intelligence-but also to heighten their aggression according to Martian standards. Further links to 2001 include flawed attempts to conceal the true implications of the discovery at a press conference, a sudden mysterious sound that paralyses the researchers in the pit, an octagonal corridor inside the spaceship, and a recorded memory of a "wild hunt" on Mars, a hallucinatory passage through unknown spaces that anticipates the Star Gate.

Absorbing Clarke's and Kneale's sources into Lovecraft's eschatological scheme-a God-penetrated Paradise, the Fall with creation/re-education, a Second Divine Coming-2001 participates in that naturalisation of religion that is part of the ancient astronaut thesis, including Carl Sagan's speculations: notions of gods derive from ancient contact with extra-terrestrial supreme intelligences, who left their traces in ancient monuments and/or myths, but whose influence has been subdued in later stages of human culture. ${ }^{75}$ However, we are now approaching an 

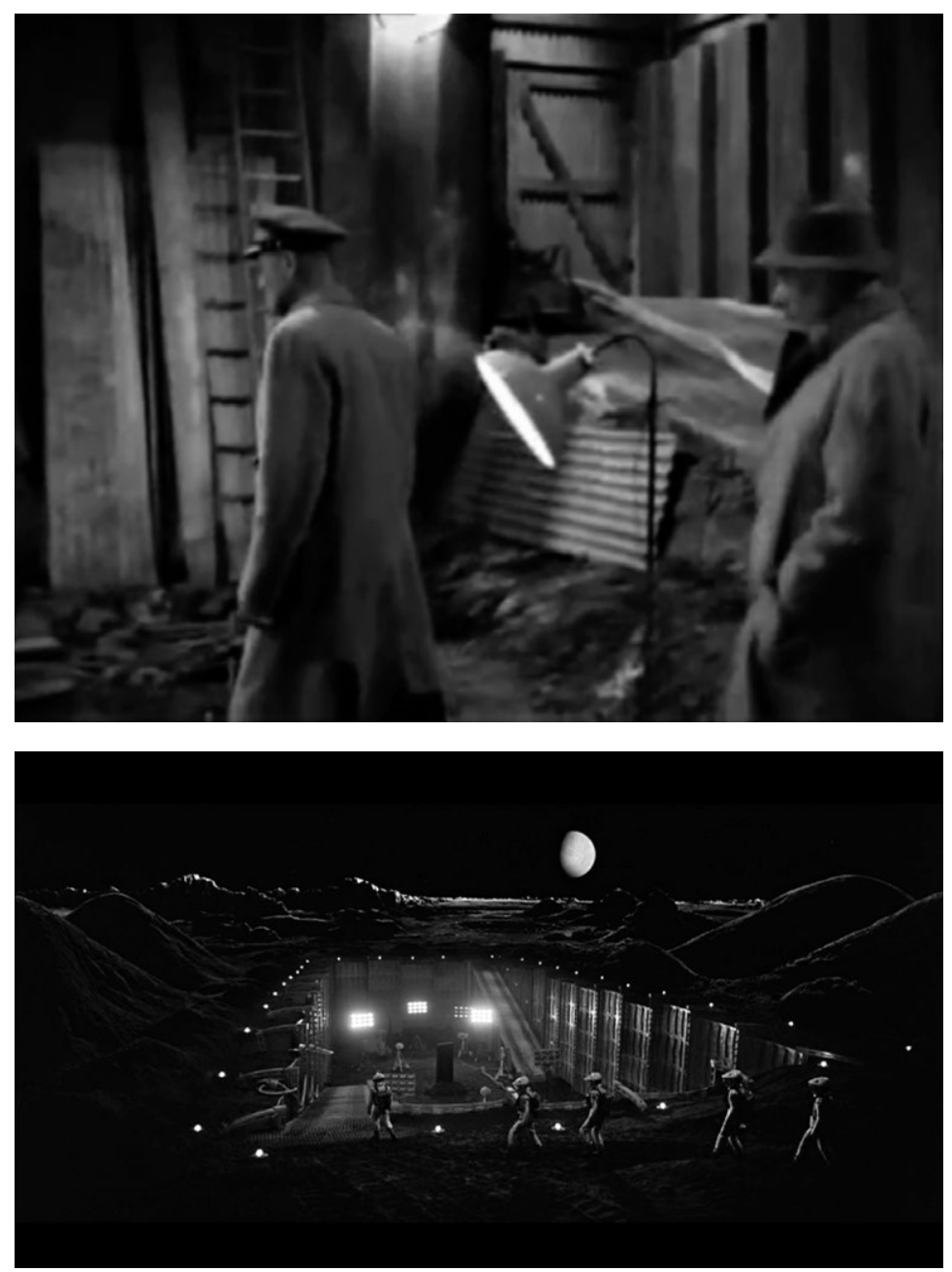

Fig. 7

Investigators in the pit, moving from ramp to alien artefact.

Still from Nigel Kneale's BBC TV series, Quatermass and the Pit (broadcast 1958-59).

Fig. 8

Heywood Floyd and his team on their way to the excavation site in the Tycho moon crater. Still from 2001: A Space Odyssey (1968). 
apocalyptical epoch in which these supreme intelligences may be rediscovered, either through encounters with them (from flying saucers to our own space expeditions), technological evolution (our modern artefacts re-approaching theirs, thereby picking up the thread left in the extra-terrestrially created ancient monuments), or subconscious visions (rediscovering the god within, from spirit to shadow). In Jung's ambivalent exegesis of flying saucers, all three interpretations are possible, revealing a convergence between (post)human evolution and alien intelligence that is rediscovered as much within human technology and minds as in a remote region of the universe.

\section{ENTROPIC MONUMENTS:}

\section{1, MINIMALISM AND EARTH ART}

The entire paleofuturist sensibility, which links modern technology to primordial telluric pasts, could also be approached through another branch of 1960s visual culture, with which 2001 has never been compared. In minimalist and earth art installations by artists such as Robert Smithson, Michael Heizer, Donald Judd, Sol LeWitt, Dennis Oppenheim, and Robert Morris, we find an aesthetic of industrially polished artefacts, and their occasional alliance with raw stone in deserts or other telluric sites, which echo several of the extra-terrestrial tableaus in 2001. These similarities could be framed by an equivalent meeting between deep future and deep past-geological, biological, cultural-for, as Michael Heizer, a son of an archaeologist, for instance, stated: "We're living in a schizophrenic period. We're living in a world that's technological and primordial simultaneously."76

Notably, the writings of Robert Smithson, a prime if also biased theorist of earth art and minimalism, develop this idea. More blatantly ironic and disillusioned than in Kubrick's work, however, it is now presented without support from any explicit ancient astronaut thesis. Smithson's point of departure was the minimalist work that emerged in 1964, with an early manifestation in Primary Structures (1966) at the Jewish Museum in New York. In this sort of work he noticed a special kind of monumentality that reminded him, firstly, of science fiction, secondly, of the duller sorts of modernist architecture-from skyscrapers, to movie house and discount centres, to "slurbs, urban sprawl, and the infinite number of housing developments of the postwar boom," including overlooked terrain vague parts like pipes, bridges and sandboxes - and thirdly, of archaic monuments, from prehistoric megaliths to the ziggurats that were mimicked on 
some of the remote rooftops of the "Ultramoderne" skyscrapers of Manhattan. ${ }^{77}$ In the industrial seriality common to artworks and recent architecture (the whole above-mentioned rationalist heritage of Jungian grey boxes and Heideggerian Enframing), and in their predominantly artificial materials (metal, glass, mirrors, plastic, concrete, etc.), Smithson sensed a pervasive entropy, an evolution in reverse, in which extreme past and future converged in the same energy drain, inertia and emptiness of ideals. Smithson's entropic temporality, enwrapped in a paradoxically energetic disillusionment, might immediately resemble a complete inversion of Kubrick's optimist extropianism, the belief in a culturally induced increase in complexity. Yet Smithson's focus on an all-pervasive crystalline matter and its blank surfaces concerns the undermining of autonomous consciousness, indeed, the organic as such, which is paralleled by 2001's paleofuturist turn, the coming together of machinic rationality and those deep material layers exposed by Jung's notion of the shadow. Not surprisingly, when discussing entropy, Smithson references Jung's writing on “The Materia Prima," de-actualised matter with pure potential, since alchemy, it seems to him, "is a concrete way of dealing with sameness."78 Smithson also approached this entropic sameness via another psychoanalytic route, the Freudian notion of the oceanic-which offers a close parallel to 2001's fusion of Homeric maritime and cosmic depths-and via dedifferentiation, the break-down of Gestalt closure, as presented by the Austrian-British art theorist, Anton Ehrenzweig. ${ }^{79}$ Rooting creativity in preconscious dedifferentiation, Ehrenzweig linked its negativistic side, entropy, to Thanatos, since death levels the difference between self and non-self, inside and outside-a breakdown of limits Smithson considers fundamental to contemporary art. 80

To Smithson, a primal framework for the "extreme sense of past and future" was the one exemplified by the American Museum of Natural History in New York, where “the 'cave-man' and the 'space-man' may be seen under one roof." 81 So it was to Arthur C. Clarke, whose discarded material for 2001 included a visit by three of Discovery's astronauts to a future version of this museum, thus freezing and making meta-statements on the living tableaus of Kubrick's “Dawn of Man” section. ${ }^{82}$ Smithson's satirical yet fascinated dissection of the museum's Hayden Planetarium (1966) may resemble a stripping of the scenic apparatus behind certain 2001 locations-for instance, juxtaposing in a photograph, the museum's didactic “Astronomia” corridor, with IBM's 

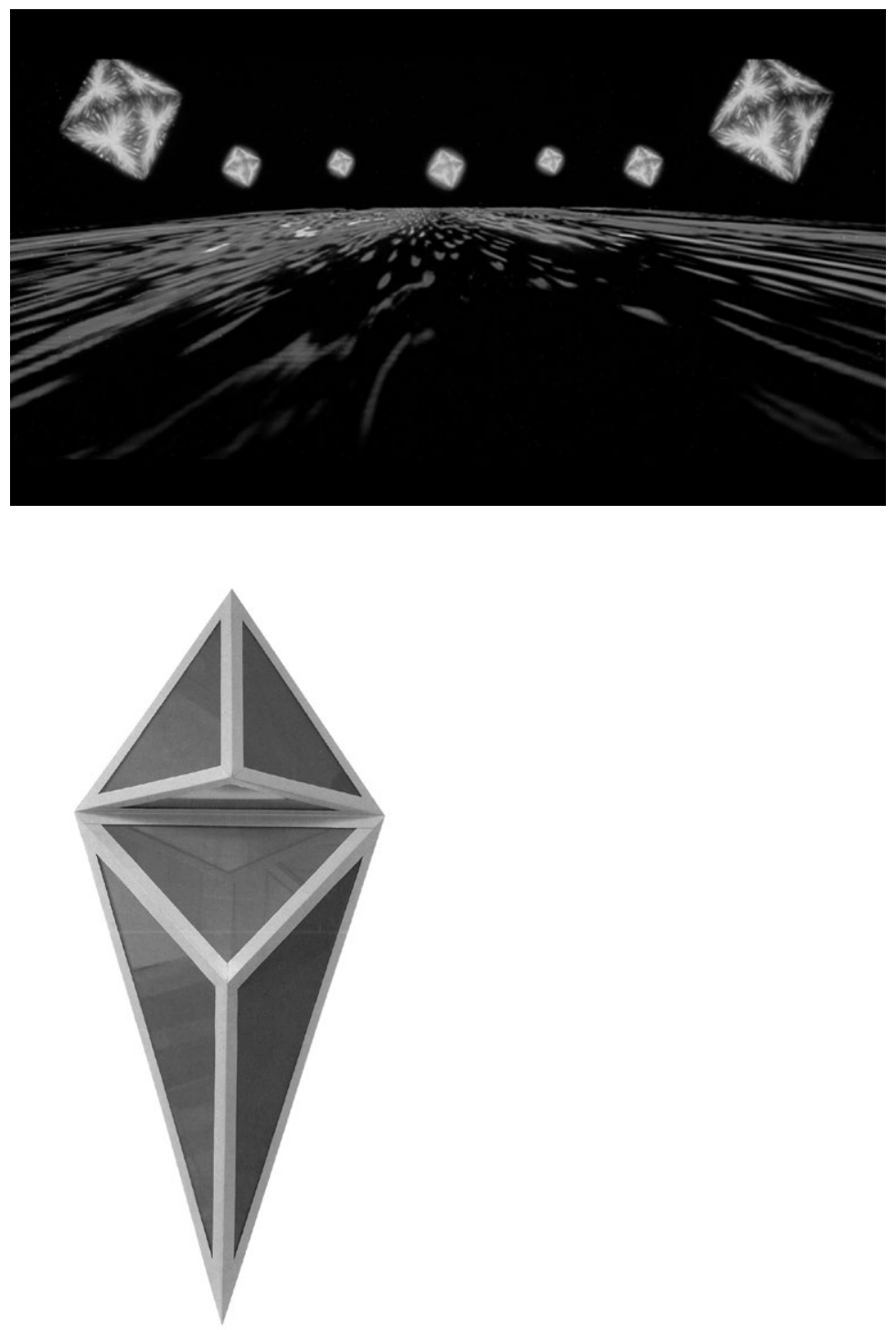

Fig. 9

Spinning crystals in the Star Gate.

Still from 2001: A Space Odyssey (1968).

Fig. 10

Robert Smithson, Untitled (1964-65), metal and plastic.

Collection Melvyn and Suellen Estrin. 
logo above its entrance (HAL's lettering being one step before IBM's); remarking that, "Rapid motion of false stars produces mild nausea or seasickness. Canned classical music adds to the effect" (mock version of the Blue Danube space ballet); noticing the paradoxically claustrophobic quality of the otherwise "dark, velvety, vast, infinite, spectacular" backgrounds around luminescent visions of "Saturn and Its Rings," "Moon in Eclipse," "Giant Nebulae of Orion," and "Lunar Landscape" (universe as womb); even linking "SOLAR SYSTEM" "\& RESTROOMS” with the same pointing hand in a reproduced sign (echoing the long instruction table for the Zero Gravity Toilet in 2001). ${ }^{83}$ Apart from his early collages and paintings, which mingle astronauts, rockets and B.E.M.s with ingredients from natural history, popular culture, and elitist art,84 Smithson also occasionally staged this kind of paleofuturist convergence in his later works, for instance, recalling 2001's reflections of instrument evolution from bone to metal in his photo collage, King Kong Meets the Gem of Egypt (1972). Here, a giant robot simian, an artificial and blownup parallel to 2001's humanoids, encounters a huge mining shovel from Ohio's coal-rich Egypt Valley. This monstrous diesel shovel, the unique product of Hanna Coal's engineers, appears as the active variant of the digging machines paused for Saturday that to Smithson resemble "prehistoric creatures trapped in the mud, or, better, extinct machines-mechanical dinosaurs stripped of their skin."85

Against this background, it seems quite logical that, say, the row of odd, semi-transparent crystals spinning over a red path in front of the deep cosmic black, one of the visions that meet Dave during the Star Gate sequence, finds a parallel in Smithson's crystalshaped sculptures, notably the one composed of metal-framed red plastic triangles (Untitled, 1964-5) (Fig. 9/10).86 To Smithson, and also to the then-minimalist sculptor, Peter Hutchinson, minimal art in general offered a congenial concretisation of the visions of science-fiction-in Hutchinson's eyes, one much more in tune with the future than the old-fashioned sci-fi visions found in pulp magazines. ${ }^{87}$ This is so, not because minimalism describes art in the future. No, "The machines are the art." 88 To Smithson, too, Donald Judd's "pink-plexiglas box" suggests "a giant crystal from another planet," 89 just as Robert Morris allegedly discloses a "backward looking future" with "erections" and "vaginas" embedded in lead, illustrating a "fossilized sexuality by mixing the time states or ideas of '1984' with 'One Million B.C...”90 As I discussed earlier, 2001 stages a similar machinic sexuality, and 
generally it displays what Gene Youngblood, already in 1970, characterised as a "minimalist aesthetic of primary structures." 91 Kubrick's film makes Smithson's entropic alliance between these structures and modernist architecture, the most technological of the arts, graspable, since sculptural forms are often foregrounded from their embeddedness in the purified functionalist repertoire of geometrically clean volumes, artificial materials, and whiteness interrupted by the occasional red. In certain sequences, this semiisolation through truncation and fragmentation creates the effect of minimalist installations, concretely extending to minimalism what Michael Heizer said of Hatshepsut's temple at Luxor: "The subject is architecture, the result is sculpture." ${ }^{2}$ Consider, for example, Discovery's long series of identical nuclear energy units, gradually presenting themselves as they pass by the camera, accompanied by the melancholic tones of Khachaturian's Gayane Ballet Suite (1941-42), or the rectangular, transparent terminals, rising one by one when Dave disconnects them from their base in HAL's Logic Memory Center. Bathed in red light, these glass boxes look like Judd's work in miniature (Fig. 11/12).

Fundamental to 2001's minimalist aesthetic is the black monolith, which Kubrick himself declared "a pretty fair example of 'minimal art'."93 Only its verticality-perhaps expressive of Kubrick's extropian strivings-distinguishes it from the typically more horizontal primary structures, including the many sci-fi "monuments," that Smithson adds to the minimalist family. John Taine presents thousands of "broad, low pillars" placed in parallel rows in a green luminescent desert (The Time Stream, 1931). Each of J.G. Ballard's "megaliths" on a surrealist beach, with frozen time, is a perfect cube, 15 feet high ("The Terminal Beach," 1964). ${ }^{94}$ Indicating that this is indeed a paleofuturist freezing, Smithson compares them to Stonehenge and The Great Pyramid, both considered a sort of "primers," resisting corruption, enigmatic computers privileging language over visibility. Does the black monolith not become such an enigmatic computer when it aligns itself with the sun, transforming sunrise to high noon? Kubrick at least compares 2001's alignments of sun, earth, and moon, and of Jupiter and its moons (together with the monolith) with that seen at Stonehenge. These configurations indicate "something magical and important about to happen." 95

What made the "monuments" of science fiction especially appealing to the paleofuturist sensibility were their "geological" and "archaeological" dimensions: their frequent placement in environments of raw earth and stone, whether the Earth's deserts, 

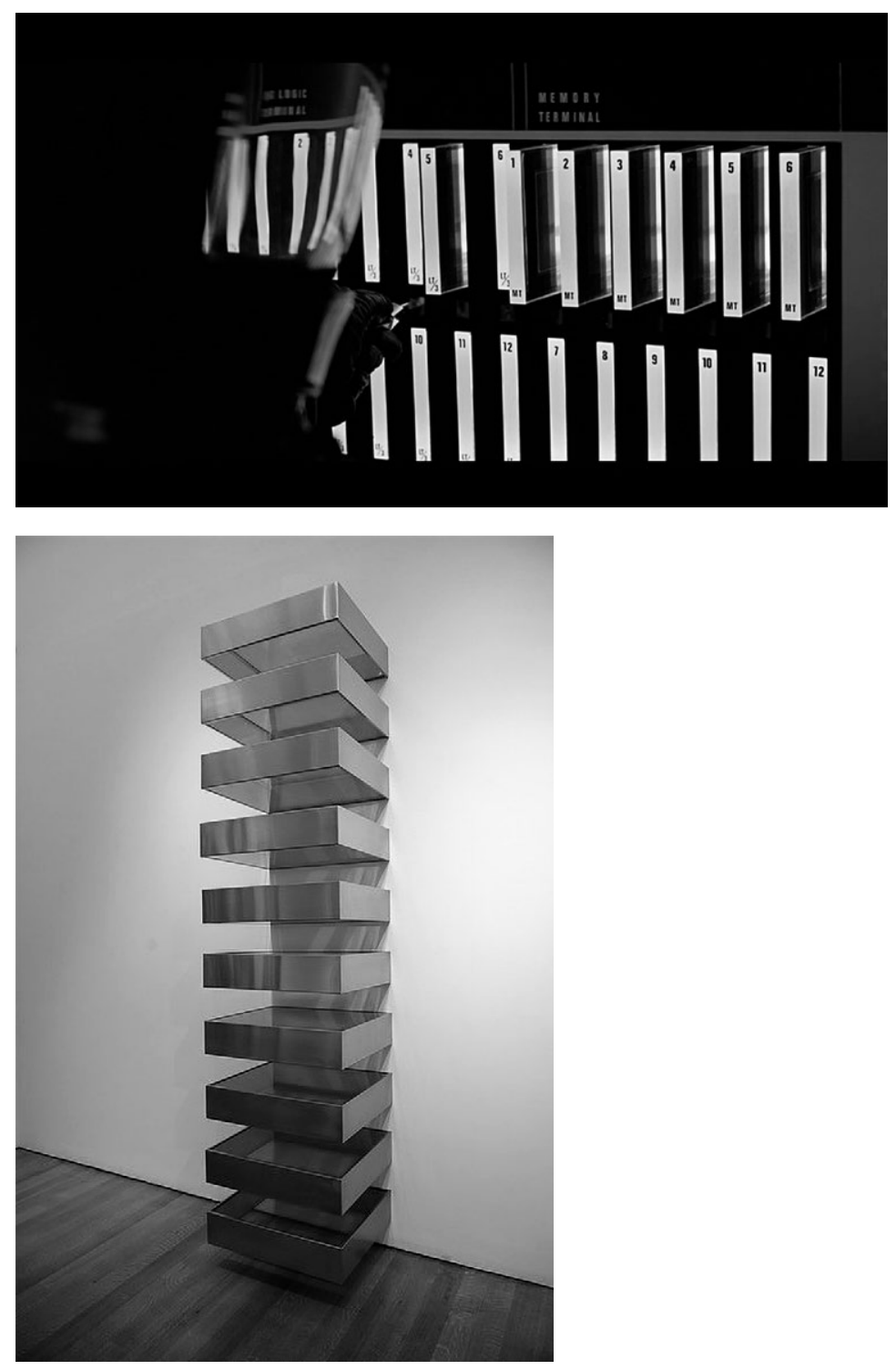

Fig. 11

David Bowman deactivating the terminals in HAL 9000's Logic Memory Center. Still from 2001: A Space Odyssey (1968).

Fig. 12

Donald Judd, Large Stack (1968), stainless steel and amber plexiglass. Kansas City, Nelson-Atkins Museum of Art. 

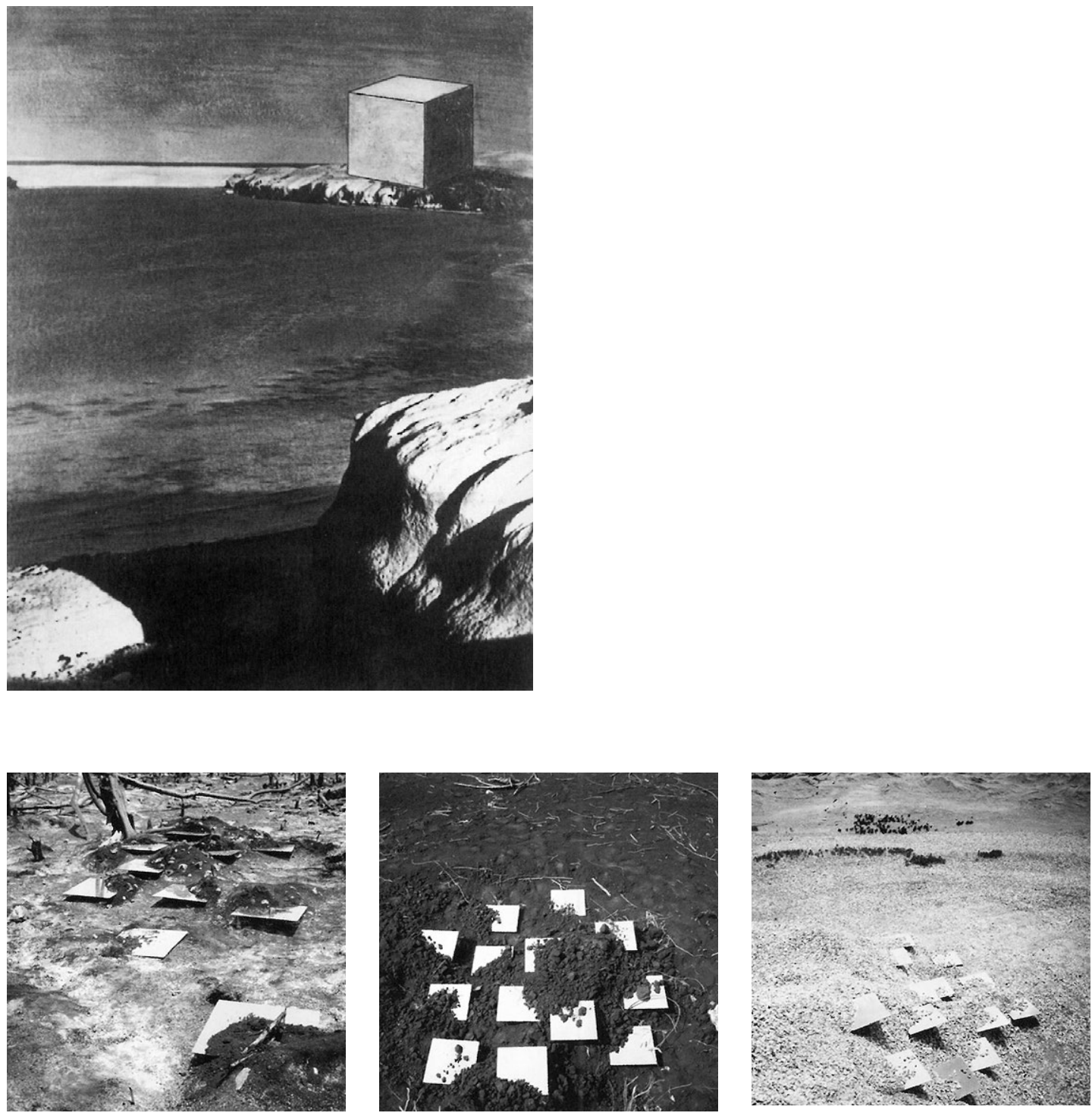

Fig. 13

Robert Smithson, Proposal for a Monument at the Red Sea (1966), b/w photograph. New Jersey, private collection.

Fig. 14

Robert Smithson, Nos. 1-3 from the series, Yucatan Mirror

Displacements (1-9) (1969), Cibachrome prints from chromogenic

$35 \mathrm{~mm}$ slides. New York, Solomon R. Guggenheim Museum. 
destroyed environments, or the truly virginal wildernesses of other planets and moons. This is also what paves the way from 2001 to earth art - the substructure of minimalism (and Smithson's specialty) that emerged on both sides of the Atlantic in 1966-68. For instance, the cubic structure on a rocky beach in Smithson's photo collage, Proposal for a Monument on the Red Sea (1966; III. 13), may be said to resemble a squarer version of 2001's monolith. Seeing the sketch for this monument or Smithson's soon to follow rows of mirrors jutting from piles of earth and stone, whether in their wilderness sites or their displacement to the non-sites of gallery spaces (Fig. 14), one experiences a joyful thrill in response to the confrontation between polished, geometrised material and raw earth, which resembles the feeling evoked by the monolith tableaus in 2001: astonishment at the alien presence of geometry in the middle of chaotic stones, yet also an uncanny recognition of a suppressed alliance between the strictly ordered and the completely disordered, between the artificial machines of the deep future and the haphazard geology of the deep past-geological crystals offering the secret bridge between now and then.

This coincidentia oppositorum that bypasses the organic is nicely encompassed by Smithson's adoption of entropy, the thermodynamic notion of decreasing differentiation in closed physical systems. ${ }^{96}$ Curiously, in contrast to the popular understanding of entropy as increasing disorder, Smithson's analyses of entropy have their focal point in the highly ordered artefacts of industrialist production: the shiny grids of modernist functionalism and the cubes of minimalism, both echoing the crystalline structures of nature. To be sure, Smithson cites physicist and Nobel laureate Peircy Williams Bridgman on the rather counter-intuitive observation on crystal generation in a supercooled liquid that, "the crystal is the seat of greater disorder than the parent liquid." 97 However, Smithson links the entropy of the industrial "monuments" and their sci-fi parallels to their encompassing sameness, blank surfaces and an energy drain, each of which prefigures the entropic heat death of the universe. For some reason, Smithson rarely uses the notion of entropy in its most obvious setting in an earth art context, the rocky chaos of the wilderness, claiming in interviews, for instance, that "Geology has its entropy too, where everything is gradually wearing down." 98 Or, "Geology has its own kind of entropy, that has to do with sediment mixtures."99

Nonetheless, Smithson often invokes entropy explicitly, or approaches it via Ehrenzweig's related notion of dedifferentiation, 
when talking about environmental sites that combine the untouched and the fabricated, such as construction sites, ruins, quarries, and mines. Rising buildings (construction sites) are marked by entropy as much as the finished buildings' leftovers, be they ruins (their worn-down selves), quarries, or mines (their worn down surroundings). ${ }^{100}$ Construction and ruin may be seen as inorganic forces that mirror each other, since each evades the coherence of the organic and the organised. When Smithson, simultaneously with (but apparently independently of) gestalt theoretician Rudolph Arnheim, located entropy as much in geometrical order as in disordered chaos, this would be supported by slightly later complexity theory. ${ }^{101}$ Thus, in contrast to complex structures generated through evolutionary processes, random and orderly systems converge by both lacking marks of their coming-into-being, what is variously termed thermodynamic depth (Seth Lloyd and Heinz R. Pagels) or logical depth (Charles Bennett). ${ }^{102}$ The more the elements of a mass-the molecules of a gas, the stones of a desert, the brushstrokes of an abstract painting-break into smaller units that increase the encompassing heterogeneity of the mass, the more this infinitesimally differentiated but randomly distributed chaos will approach a state that, from a certain distance, appears as its exact opposite, an increasingly homogenized and greyish sameness whose external parameters could be taken as orderly. Whether this mass should be categorised as chaos (with enormous amounts of inaccessible information) or order (with information approaching zero) is a question of the observer's distance, and the two poles determine each other dialectically. Moreover, as art historian Rosalind Krauss has remarked, developing Hubert Damisch's ideas on cloudy painterliness, simple repetitive ordered patterns, such as the dense grids in Agnes Martin's minimalist paintings, also, at a distance, generate surfaces of sameness, whose underlying patterns may just as well have been chaotic when inspected closer up. 103

Smithson's notion of entropy easily applies to 2001, since outer space, drained of organic life, becomes the domain par excellence for entropic phenomena: the monotony of infinite black space, of rocky surfaces of moons, of gaseous planets, and of their mirror images in the habitations that humans use to shield themselves in these hostile areas, the hard inorganic space architecture, structured as grids and shiny surfaces. One might object that the aesthetics through which Kubrick approaches these spaces pertains more to an awe-invoking sublime than to 
Smithson's disillusioned entropy. ${ }^{104}$ But entropy may be seen as a collapsed sublime. Based, like entropy, on non-enclosed, mostly inorganic matter, from amorphous chaos to geometric seriality, the sublime observes these from a still secure distance, invoking what Edmund Burke termed delight, the relief of being saved from destruction. ${ }^{105}$ On the other hand, in the entropic phenomenology of minimalism and earth art, this Cartesian distance has shrunk. Bringing space "down into an abstract world of mineral forms," Judd, for instance, is involved in what Smithson calls the "The Deposition of Infinite Space."106 Thus, Kubrick's inorganic hovers between a sublime distance, sustained by extropianism's escape from matter, and an entropic myopia, which re-absorbs itself into matter.

In both 2001 and earth art proper, the encounters between the entropic poles of order and disorder are heightened by the dialectics of artefacts' burial and re-exposure. In 2001 this is explored when the monolith, now called TMA-1 (Tycho Magnetic Anomaly-1), is recovered from beneath the rocky surface of the moon. With an almost uncanny sense for the movements of advanced contemporary art, this scene was the first one filmed-shot in late December 1965, with the additions of the moon setting, black sky, and earth added a year later-thus participating in the very genesis of earth art.107 As it stands in its artificially constructed hollow, with sloping ramps and metal sheets screening off the raw moon walls, and revealed in the ice-cold light from the frames of rectangular spotlights, the monolith presents that entire pleasure of the excavation process, the digging out and removal of tons of earth, which was already glimpsed in Quatermass and the Pit, and which would become purified through earth art. In a wide array of contemporary artworks dealing with artificial hollows in the earth, consider, for instance, Michael Heizer's huge Double Negative (1969-70; III. 15), which creates two rectangular voids across a Nevada desert gulf, or his Displaced-Replaced Mass (1969), three granite rocks placed in depressions lined with concrete. ${ }^{108} \mathrm{With}$ regard to the ramps of the moon excavation, echoes are found in Heizer's Dissipate (Nine Nevada Depressions 8) (1968), five rectangular wooden boxes with sloping interiors, inserted in an irregular pattern in the flat bottom of a dried-up lake in Black Rock Desert, Nevada. ${ }^{109}$ Furthermore, $T M A-1$ 's dialectics of the burial and exposure of a sculptural monument has parallels in works such as Dennis Oppenheim's Excavated Sculpture (1967) and, perhaps most notably, in Sol LeWitt's nine-part photo-documented performance, Buried Cube 

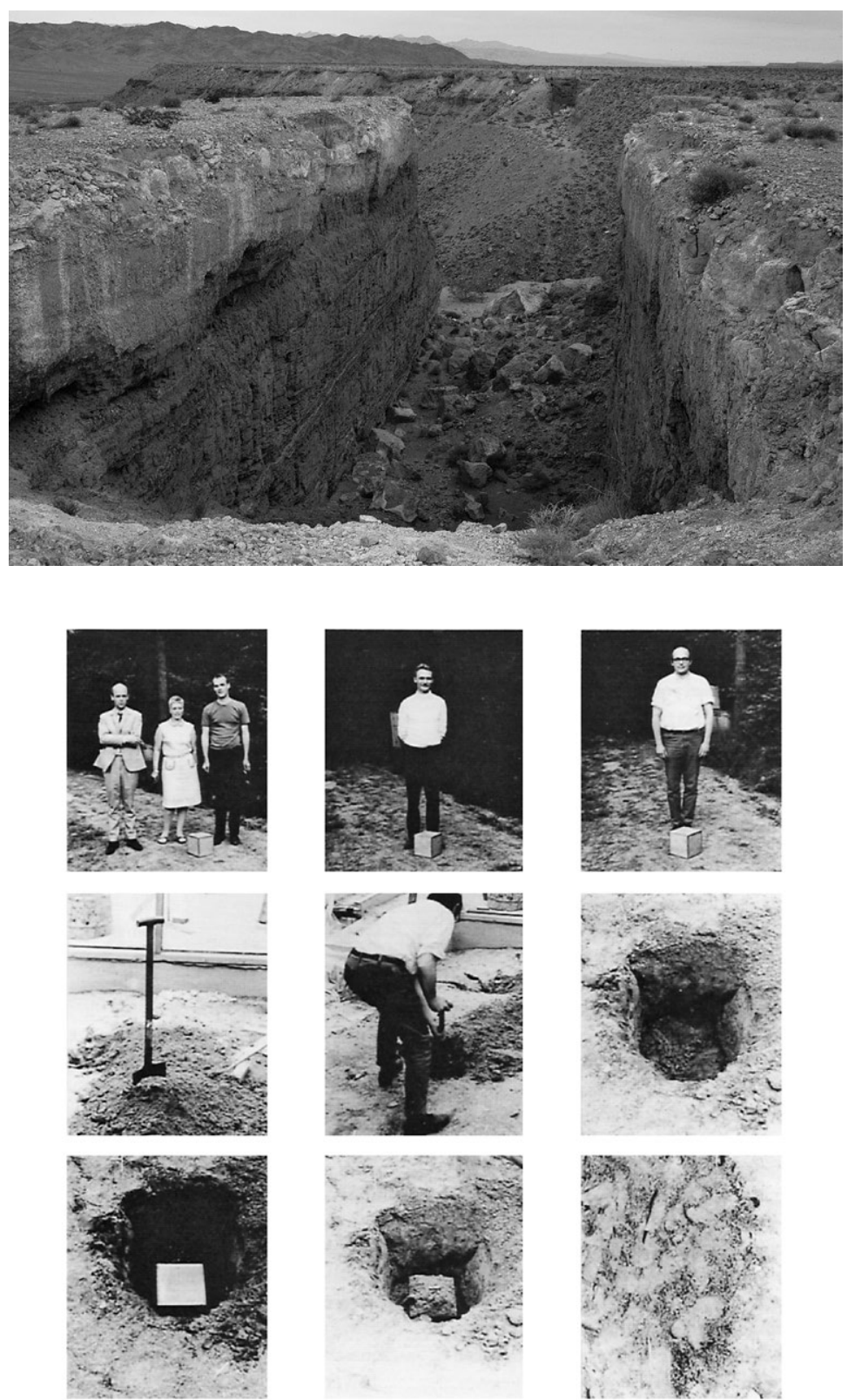

Fig. 15

Michael Heizer, Double Negative (1969-70), earth art intervention.

Mormon Mesa, Overton. Nevada.

Fig. 16

Sol LeWitt, Buried Cube (1968), 10-inch, stainless steel cube. Nine-part photo documentation of performance in Bergeyk, Holland. In the top row of photographs are (left to right) the artist's patrons and hosts, Carel and Mia Visser, Dick van der Net, a metal fabricator, and LeWitt. 
(1968; III. 16), which took place beside a Gerrit Rietveld mansion in Bergeyk, Holland.110 Recalling that entanglement of banality and awe evident in the astronauts posing for a souvenir photograph in front of the monolith, the burial of this 10 -inch stainless steel box is also part of a photo session. Here, the local "crew" comprised LeWitt's Dutch friend, Mia Visser (who was asked to place an artwork, now unknown, inside the cube), her husband, one of their friends, the metal fabricator, and LeWitt himself.

The title of the first American exhibition of earth art, Earth Works, in Dwan Gallery, New York, in October 1968, also drew on science fiction, the novel Earthworks (1965) by Brian Aldiss (incidentally, later collaborator with Kubrick on the unfinished A.I.). ${ }^{111}$ Similarly, Smithson's most famed work, the Spiral Jetty (1972) in Great Salt Lake, Utah, reflected a motif from Ballard's short story, “The Voices of Time” (1960). ${ }^{112}$ The entropic freezing of time, a cosmic countdown to an eternal sleep for humankind, hits the protagonist, Powers, as he enters a tripartite mandala structure in a dried-out salt lake, located in an abandoned air force testing range. Like many other earthworks, Spiral Jetty was installed in one of those American deserts that, by the nineteenth century, had mitigated the American inferiority complex about its lack of history (vis-à-vis Europe's longer history) by exposing deeper layers of pre-human history-apart from in Utah, deserts in Arizona, Nevada, and New Mexico. ${ }^{113}$ In a striking parallel, one of the two locations for 2001's final landscapist Star Gate sequence, the negatively-coloured and solarised closing-in on base matter, was in fact Arizona's-appropriately namedMonument Valley (the other being the Hebrides). ${ }^{114}$ Otherwise, as we have seen, suburban deserts-construction sites, terrains vagues, quarries-would do for the earth artists. Setting out to explore the geology of the quarries of the First Watchung Mountain, New Jersey, with his wife, Nancy, and Donald Judd and his wife, Julie, Smithson bluntly declares that the Great Notch Quarry “resembled the moon,” and indeed, Smithson's attention to the site's raw rocky quality, with its chaos of cracks and an infinity of surfaces, is in tune with 2001's exposition of the thrillingly deserted moonscapes when the shuttle approaches Tycho. ${ }^{115}$

When touched on in existing art history, the paleofuturist sensibility of minimalism and earth art has been somewhat divided between forward- and backward-looking modes. A rare futurist framing of modern sculpture in its entirety, including minimalism, is delivered in the visionary but now largely forgotten 
Beyond Modern Sculpture (1967), by the artist and art theorist Jack Burnham. ${ }^{116}$ Burnham was - like Kubrick and his consultant on extra-terrestrial intellegence, Frederick Ordway, whose work with Roger MacGowan Burnham in fact refers to - an extropianist who believed that intelligent machines were about to take over evolution, recreating life through technology. ${ }^{117}$ Sculpture's recent move towards information, systems, and the totality of the environment, as seen in minimalism, was a preparatory step toward "our destination as a post-human species."118 Seen through Burnham's lens, it makes perfect sense that the alien, post-biological intelligence that wants to absorb lower stages of evolution into its force field in 2001 chooses to communicate through a piece of minimalist sculpture. As Hutchinson says of such art, "It has an alien look and might have been made on another planet.”119 However, at this point, Burnham's futurism is gained at the expense of sensing the neo-archaism of modern art. Only later would he suggest the possibility that “... art in its last stages constitutes a structural reversion to the infantile stages of human development." ${ }^{120}$ Lucy Lippard systematically unpacks this observation in Overlay: Contemporary Art and the Art of Prehistory (1983), yet now without the futurist sensibility. ${ }^{121}$ Thus, without resorting to either Smithson's sarcastic sci-fi or any ancient astronaut theses, Lippard layers prehistoric monuments, ornaments, and rituals with those of minimalism, earth art, and performance. Ironically, we have to resort to wild speculation on alien intervention in prehistory-in this case Ordway and MacGowan's-to get the full paleofuturist appreciation of modern art's strangeness, its corridor from prehistory to the future bypassing humanism: "Doubtless, many of us who view what passes for art in this modern age feel prone to attribute it to an alien influence." 122

To a large extent, the re-evocation of ancient cultures and the deep geological strata is part of minimalism's and earth art's famed phenomenological quality, their evoking of a sense of being physically entangled with non-representational objects, lumps of exposed matter. ${ }^{123}$ Strikingly, then, this breaking out of sculpture's illusionist sphere and into a direct engagement with the viewer's exposed body happens through a corresponding draining-out of sculpture's usual referent, the anthropomorphic body, challenging the viewer to adapt to essentially dehumanised, non-organic forms. A parallel fossilising movement is felt inside the spaces of 2001, and in general, in Kubrick's later work. Like classical sculpture, with which minimalism breaks, mainstream 


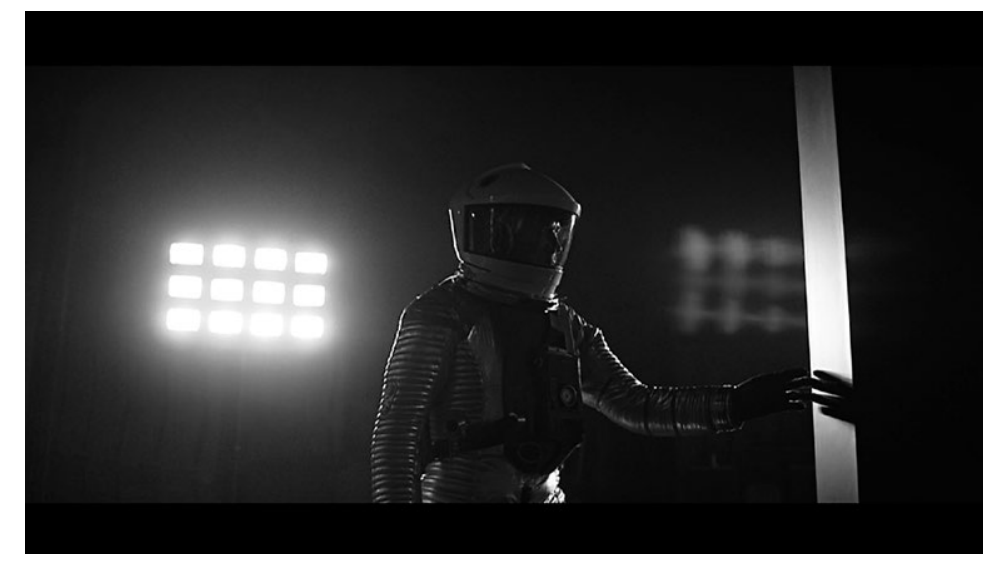

Fig. 17

Heywood Floyd touching the monolith in Tycho crater. Still from 2001: A Space Odyssey (1968). 
films have human figures as their centre of attention, and are driven by these figures' narrative acts and utterances, thereby reducing the less organised environment, space, to mere background. ${ }^{124}$ However, the non-verbal, subconscious quality, the renewed mythic language with which Kubrick intentionally seizes the viewer in 2001, is achieved by foregrounding these former backgrounds, and, indeed, embarking on an odyssey into space and its materials. ${ }^{125}$ Since in 2001, this space, a celestial echo of tellurian minimalism and earth art, is the location of the most entropic and least organised phenomena-infinite vacuum, rocky terrain, hard geometric containers-its human actants, logically, seem to fossilise in their adaptation to it. ${ }^{126}$ In a parallel with Smithson's fondness for mannerism-the inorganic's invasion of anthropomorphic bodies in an otherwise naturalistic framework-this could indeed be termed a mannerist move.127

The scene with the humanoids gradually approaching their hands to the hard surface of the monolith almost suggests metacommentary on the new and more direct phenomenological relationship to things that manifests in both minimalism and Kubrick's film. The apes' initial reaction-the anxious withdrawing of their hands, as though the surface were glowingmay recall the permanent one of formalist critic Michael Fried, who denigrated minimalism's break-down of the distance to the viewer, what he termed its literalism and theatricality. ${ }^{\mathbf{1 2 8}}$ But, again, the deeper mystery of the monolith-and the field that minimalism explores-is not merely its invitation to touch matter, but matter's reconciliation with intelligence. In the midst of others' phenomenological framing of minimalism, Sol LeWitt directly categorised it as conceptual art, and Robert Morris noted its oscillation between "the known constant and the experienced variable.”129 Perhaps Heywood Floyd's calm re-touching of the monolith on the moon, his glove casting a deep shadow on its shiny surface, allegorises this mystery more fully (Fig. 17). As minimalist sculptor Carl Andre remarked in 1969, "An astronaut who slips out of his capsule in space has lost his environment, any living organism has an environment."130 Thus, Floyd's protective environment, his space suit, may be seen as a materialisation of that conceptual framework, the passage to intelligence, through which matter-phenomenology's foundation exposed through the Jungian shadow-is re-approached in the paleofuturist circle. 
1 Robert Ardrey, African Genesis: A Personal Investigation into the Animal Origins and Nature of Man (London: Collins, 1961), 175-207.

2 "A Sedimentation of the Mind: Earth Projects," Artforum (September 1968), reprinted in Robert Smithson, Robert Smithson: The Collected Writings, ed. Jack Flam (Berkeley, Los Angeles and London: University of California Press, 1996), 100-113, citation 101.

3 Robert Smithson, "Entropy and the New Monuments," Artforum (June 1966), reprinted in Robert Smithson: The Collected Writings, 9.

4 Joseph Gelmis, "The Film Director as Superstar: Stanley Kubrick" [1970], reprinted in Gene D. Phillips, Stanley Kubrick Interviews (Jackson: University Press of Mississippi, 2001), 91.

5 Friedrich Nietzsche, Thus Spoke Zarathustra: A Book for All and None, ed. Adrian del Caro and Robert B. Pippin, trans. Adrian del Caro (Cambridge: Cambridge University Press, 2006), "Zarathustra's Prologue," 5-6.

6 Nietzsche, Thus Spoke Zarathustra, "On the Three Metamorphoses," 16-17.

7 Philip Kuberski, “Kubrick's Odyssey: Myth, Technology, Gnosis," Arizona Quarterly: A Journal of American Literature, Culture, and Theory 64, 3 (Autumn, 2008): 51-73.

8 Nietzsche, Thus Spoke Zarathustra, "On the Three Metamorphoses," 17.

9 Nietzsche, Thus Spoke Zarathustra, 4, "The Sign," 266.

10 Cp. Extropy: The Journal of Transhumanist Thought, issued by Max More in 1988. Hans Moravec, a promoter of the idea of an uploadable mind, later became one of Kubrick's favourite authors, see Jerold J. Abrams, "Nietzsche's Overman as Posthuman Star Child in 2001: A Space Odyssey," in The Philosophy of Stanley Kubrick, ed. Jerold J. Abrams (Lexington, Kentucky: University Press of Kentucky, 2007), 258.

11 Gelmis, "The Film Director as Superstar," 93.

12 See Roger A. MacGowan and Frederick I. Ordway, III, Intelligence in the Universe (Englewood Cliff (NJ): Prentice-Hall, 1966), especially 178-245 (citation 182), and Arthur C. Clarke, "Foreword," in MacGowan and Ordway, Intelligence in the Universe, $v$.

13 Gelmis, "The Film Director as Superstar," 93.

14 Eric Norden, "Playboy Interview: Stanley Kubrick," Playboy (September 1968), reprinted in Phillips, Stanley Kubrick Interviews, 50 and 56 (citation).

15 C.G. Jung, Flying Saucers: A Modern Myth of Things Seen in the Sky, trans. R.F.C. Hall (London: Routledge and Kegan Paul, 1959), 169; Norden, "Playboy Interview," 51-52 and 57-59.

16 For instance, see Rob Ager, "Kubrick: and beyond the cinema frame," an in-depth analysis of 2001: A Space Odyssey (2008), Ch. 2, "The Meaning of the Monolith": http://www.collativelearning.com/2001\%20 chapter\%202.html

17 Nietzsche, Thus Spoke Zarathustra, 4, §§10-11, 263.

18 Julian Rice, Kubrick's Hope: Discovering Optimism from 2001 to Eyes Wide Shut (Lanham (MD), Toronto and Plymouth: The Scarecrow Press, 2008), 41; Philip Kuberski, Kubrick's Total Cinema: Philosophical Themes and Formal Qualities (New York and London: Continuum, 2012), 78.

19 Jane Bennett, Vibrant Matter: A Political Ecology of Things (Durham and London: Duke University Press, 2010).

20 Cited in Piers Bizony, The Making of Stanley Kubrick's 2001: A Space Odyssey (Cologne: Taschen, 2014), 14.

21 The chain until Discovery, see Leonard F. Wheat, Kubrick's 2001: A Triple Allegory (Lanham (MD) and London: The Scarecrow Press, 2000), p. 12. Wheat, however, calls the entry of Discovery a birth.

22 John Izod, "Transforming the Final Ghost: The God within," in Myth, Mind and the Screen: Understanding the Heroes of Our Time (Cambridge: Cambridge University Press, 2001), 185-203; Kuberski, “Kubrick's Odyssey"; Rice, Kubrick's Hope.

23 Kuberski, “Kubrick's Odyssey," 60.

24 Gelmis, "The Film Director as Superstar," 92-93.

25 C.G. Jung, The Structure and Dynamics of the Psyche, trans. R.F.C. Hull, Collected Works, eds. Herbert Read, Michael Fordham, Gerhard Adler and William McGuire, vol. 8 (London: Routledge and Kegan Paul, 1960), §103, 55.

26 Nietzsche, Thus Spoke Zarathustra, "Zarathustra's Prologue," §4, 8.

27 Gelmis, "The Film Director as Superstar," 92-93.

28 Norden, "Playboy Interview," 51-52.

29 Jung, Flying Saucers, 14-15.

30 Jung, Flying Saucers, 30-41.

31 Carl Gustav Jung, Psychology and Alchemy, transl. R.F.C. Hull, Collected Works, vol. 12, eds. Herbert Read, Michael Fordham, Gerhard Adler and William McGuire (Princeton: Princeton University Press, 1968 [1953]), esp. 170-71 and 317-44; Izod, in Myth, Mind and the Screen, 196-98, drawing on Richard A.J. Hellen and Philip M. Tucker's "The Alchemical Art of Arthur C. Clarke," Foundations 41 (1987): 30-41, indicates some of the alchemical ingredients but does not connect them in a thorough synthesis. For "squareness" in alchemy as the meeting of chthonic and mercurial, metal and spirit, see Jung, Flying Saucers, 135.

32 Jung, Flying Saucers, 166-74.

33 Carl Gustav Jung, Two Essays on Analytical Psychology, trans. R.F.C. Hull, Collected Works, vol. 7, eds. Herbert Read, Michael Fordham, Gerhard Adler and William McGuire (Princeton: Princeton University Press, 1966 [1953]), §250, 160.

34 C.G. Jung, Memories, Dreams, Reflections, recorded and edited by Aniela Jaffé, trans. Richard and Clara Winston (New York: Vintage Books 1989 (1961) [1960]): "Visions," 289-90.

35 Jeremy Bernstein, "Beyond the Stars" [1965], in Phillips, Stanley Kubrick Interviews, 18. I thank Jonas Bencard for the musical point.

36 Jung, Memories, Dreams, Reflections, 291.

37 Jung, Memories, Dreams, Reflections, 295-96.

38 Jung, Memories, Dreams, Reflections, 296.

39 Jung, Memories, Dreams, Reflections, 292. On threedimensional existence vs. eternity, also see 321 ("On Life after Death").

40 Gelmis, "The Film Director as Superstar," 91. 
41 Jung, Memories, Dreams, Reflections, 293.

42 Ardrey, African Genesis, 143. This has not been noted before.

43 Jung, Flying Saucers, 176. Yet another source may be Lennart Nilsson's photo of the foetus in a semitransparent, whitish womb, similarly hovering, backlit against a deep black background, reproduced on the cover of Life magazine (April 30, 1965). I thank Inge Hinterwaldner for this reference.

44 Robert Phillip Kolker, A Cinema of Loneliness (New York and Oxford: Oxford University Press, 1988), 87, also calls Kubrick "an anti-humanist," with figures determined "mechanistically," "sometimes by their passions," and "always by the rituals and structures," which "they allow ... to control them."

45 Jean-François Lyotard, The Inhuman: Reflections on Time, trans. Geoffrey Bennington and Rachel Bowlby (Cambridge: Polity 1991 [1988]), 1-4.

46 Ardrey, African Genesis, 208-25. Also see Rice, Kubrick's Hope, 26-28.

47 Ardrey, African Genesis, 23 and 175-207, with citation 194.

48 Ardrey, African Genesis, 205 (my emphasis).

49 See the 1965 script on the Kubrick site: http://www.visual-memory.co.uk/amk/doc/0057.html

50 Arthur C. Clarke, 2001: A Space Odyssey (London: Arrow Books, 1968), 256.

51 Carolyn Geduld, Filmguide to 2001: A Space Odyssey (Bloomington and London: Indiana University Press, 1973), 63, states that Kubrick removed the destruction of the nuclear weapons in order not to repeat $D r$. Strangelove.

52 Le Corbusier, Towards a New Architecture (London: Architectural Press, 1960 [1923]), 115-19.

53 Cp. Scott Loren, "Mechanical Humanity, or How I Learned to Stop Worrying and Love the Android: The Posthuman Subject in 2001: A Space Odyssey and Artificial Intelligence: A.I.," in Stanley Kubrick: Essays on His Films and Legacy, ed. Gary D. Rhodes, (Jefferson (North Carolina) and London: McFarland \& Company, 2008), 211-31, esp. 230.

54 Adorno, Negative Dialectics, trans. E.B. Ashton (London and New York: Routledge, 1973 [1966]), 67 and 35758; Max Weber, "Die protestantische Ethik und der Geist der Kapitalismus" [1904-05], in Gesammelte Aufsätze zur Religionssoziologie I (Tübingen: J.C.B. Mohr, 1920), 203: "ein Stahlhartes Gehäuse"; Martin Heidegger, "The Turning" [1949], in The Question Concerning Technology and Other Essays, trans. William Lovitt (New York: Harper Torchbook, 1977 [1962]), 42.

55 Heidegger, The Question Concerning Technology, 42.

56 Clarke, 2001: A Space Odyssey, 170-71.

57 For these and other sources, see the account by Kubrick's assistant, Anthony Frewin, “2001: The Prologue that Nearly Was - The Subjects that Always Were," in Kinematograph 20 (Frankfurt a.M.: Deutsches Filmmuseum, 2004): 132; I.S. Shklovskii and Carl Sagan, Intelligent Life in the Universe (San Francisco: Holden-Day, Inc., 1966). Shklovskii's speculations on Mars's satellites as possibly artificial are commented on in Norden, "Playboy Interview," 55.
58 MacGowan and Ordway, Intelligence in the Universe, 291.

59 MacGowan and Ordway, Intelligence in the Universe, 289 (citation); Shklovskii and Sagan, Intelligent Life in the Universe, 454-64.

60 Shklovskii and Sagan, Intelligent Life in the Universe, 436.

61 MacGowan and Ordway, Intelligence in the Universe, 313-14. Also Shklovskii and Sagan, Intelligent Life in the Universe, 461-62.

62 Shklovskii and Sagan, Intelligent Life in the Universe, 462; Gelmis, "The Film Director as Superstar," 91.

63 Frewin, "2001: The Prologue that Nearly Was," 131.

$64 \mathrm{http} / /$ www.hplovecraft.com/writings/texts/fiction/ cc.aspx Jason Colavito, "Charioteer of the Gods: An investigation into H.P. Lovecraft and the invention of ancient astronauts," originally published in Skeptic 10,4 (2004), see http://jcolavito.tripod.com/lostcivilizations/ id26.html

65 http://www.hplovecraft.com/writings/texts/fiction/ mm.aspx

$66 \mathrm{http} / / / \mathrm{www} . h$ plovecraft.com/writings/texts/fiction/ cs.aspx

67 Ordway and MacGowan, Intelligence in the Universe, pp. 291-310; Louis Pauwels and Jacques Bergier, Le matin des magiciens: introduction au réalisme fantastique (Paris: Gallimard, 1960); Robert Charroux, Histoire inconnue des hommes depuis cent mille ans (Paris: Éditions Robert Laffont, 1963); Ronald Story, The Space Gods Revealed: A Close Look at the Theories of Erich von Däniken (New York: Barnes and Noble, 1976).

68 Hergé, Vol 714 pour Sydney (Paris: Casterman, 1968).

69 Story, The Space Gods Revealed, xi-xiv.

70 Susan Sontag, "Fascinating Fascism," The New York Review of Books (February 6, 1975): 40.

71 Arthur C. Clarke, "The Sentinel" [1950], in The Making of Kubrick's 2001, ed. Jerome Agel (New York, Signet: 1970), 19-28.

72 Agel, The Making of Kubrick's 2001, 24; Arthur C. Clarke, The Lost Worlds of 2001 (London: Sidgwick and Jackson, 1972), 44.

73 Clarke, "The Sentinel," 22; Nietzsche, Thus Spoke Zarathustra, 1, §6, 11.

74 Geduld, in Filmguide to 2001, 21-22, briefly notices the overall thematic similarity. See otherwise https:// en.wikipedia.org/wiki/Quatermass_and_the_Pit. The series can be found on YouTube. It was remade as a film by Roy Ward Baker: Five Million Years to Earth (1967).

75 MacGowan and Ordway, Intelligence in the Universe, 300-314; Carl Sagan, "Direct Contact Among Galactic Civilizations by Relativistic Interstellar Spaceflight," in Planetary and Space Science 2 (1963): 485, cited in MacGowan and Ordway, Intelligence in the Universe, 302.

76 “Interview: Julia Brown and Michael Heizer," in Sculpture in Reverse: Interview with Julia Brown, eds. Manon Lutanie, Cerise Fontaine and Raphaëlle Brin (Paris: Éditions Lutanie, 2014 [Los Angeles: The Museum of Contemporary Art, 1984]), 13.

77 Smithson, "Entropy and the New Monuments," in Robert Smithson: The Collected Writings, 10-23; 
"A Tour of the Monuments of Passaic, New Jersey," Artforum (December 1967), reprinted in Smithson, Robert Smithson: The Collected Writings, 68-74; "Ultramoderne," Arts Magazine (September-October 1967), reprinted in Robert Smithson: The Collected Writings, 62-65.

78 Smithson, "Entropy and the New Monuments," in Robert Smithson: The Collected Writings, 19; Jung, Collected Works, vol. 12, 317-44.

79 Smithson, "A Sedimentation of the Mind: Earth Projects," in Robert Smithson: The Collected Writings, 103 and 110.

80 Anton Ehrenzweig, The Hidden Order of Art: A Study in the Psychology of Artistic Imagination (London: Weidenfeld and Nicolson, 1967), 219 and 221; Smithson, "A Sedimentation of the Mind: Earth Projects," in Robert Smithson: The Collected Writings, 103; Caroline A. Jones, Machine in the Studio: Constructing the Postwar American Artist (Chicago and London: University of Chicago Press, 1996), 273 and 325-26; Simon Dell, "Spaces," in On Location: Siting Robert Smithson and His Contemporaries, ed. Simon Dell (London: Black Dog Publishing, 2008), 50-52.

81 Smithson, "Entropy and the New Monuments," in Robert Smithson: The Collected Writings, 15.

82 Arthur C. Clarke, "Ancestral Voices," in The Lost Worlds of 2001, 107-13.

83 "The Domain of the Great Bear," written together with Mel Bochner in Art Voices (Fall 1966), reproduced in Robert Smithson: The Collected Writings, 26-33.

84 Eugénie Tsaï, "The Sci-fi Connection: The IG, J.G. Ballard, and Robert Smithson," in Modern Dreams: The Rise and Fall and Rise of Pop, eds. Lawrence Alloway et al., (New York: Institute of Contemporary Art and Cambridge (MA): MIT Press, 1988), 71-74.

85 Smithson, "A Tour of the Monuments of Passaic, New Jersey," in Robert Smithson: The Collected Writings, 71; Jones, Machine in the Studio, 324, 329 and 331.

86 Geduld, in Filmguide to 2001, 60-61, remarks that the 2001 crystals probably refer to Clarke's "gold spindleshaped things" showing up in the horizon, when the pod is routed through a "cosmic switching device ... a Grand Central Station of the Galaxy."

87 Peter Hutchinson, "Science-Fiction: An Aesthetic for Science," Art International XII/8 (1968): 32-33.

88 Hutchinson, "Science-Fiction," 34.

89 Smithson, "The Crystal Land," Harper's Bazaar (May 1966), here cited from Robert Smithson: The Collected Writings, 7-10 (citation 7).

90 Smithson, "Entropy and the New Monuments," in Robert Smithson: The Collected Writings, 15. Also see Jones, Machine in the Studio, 312.

91 "The New Nostalgia," here cited from Geduld, Filmguide to $2001,87$.

92 Heizer, Sculpture in Reverse, 36.

93 Gelmis, "The Film Director as Superstar," 93.

94 Smithson, "Entropy and the New Monuments," 10; "The Artist as Site-Seer: Or, a Dintorphic Essay" [1966-67], in Robert Smithson: The Collected Writings, 340-45; J.G. Ballard, “The Terminal Beach" [1964], in The Terminal Beach (London: J.N. Dent and Sons,
1984 [1964]), 134-55; Robert A. Sobieszek, “Robert Smithson's Proposal for a Monument at Antarctica," in Robert Smithson, ed. Jane Hyun (Los Angeles: The Museum of Contemporary Art, 2004), 143-88

95 Agel, The Making of Kubrick's 2001, 80 (with no indication of source).

96 For a brilliant analysis of the reception of the concept of entropy in post-war American culture, see Caroline A. Jones, "Entropies," in Energies in the Arts, ed. Douglas Kahn (Cambridge (MA): MIT Press, 2018). I thank the author for letting me read it before publication.

97 Smithson, "Entropy and the New Monuments," in Robert Smithson: Collected Writings, 20; Peircy Williams Bridgman, The Nature of Thermodynamics (Cambridge (MA): Harvard University Press, 1941), 175.

98 "Entropy Made Visible. Interview with Alison Sky" (1973), in Robert Smithson: Collected Writings, 301-09, here 303.

99 “...The Earth, Subject to Cataclysms, is a Cruel Master," interview with Gregoire Muller, in Arts Magazine (November 1971), reprinted in Robert Smithson: Collected Writings, 253-61 (citation 256).

100 Smithson, "A Sedimentation of the Mind: Earth Projects," in Robert Smithson: Collected Writings, 110; "Entropy Made Visible. Interview with Alison Sky" (1973), in Robert Smithson: Collected Writings, 304-09; also see, without specific mention of entropy, "The Crystal Land," Harper's Bazaar, May 1966, reprinted in Robert Smithson: Collected Writings, 7-9. Also see Amanda Boetzkes, The Ethics of Earth Art (Minneapolis and London, University of Minnesota Press, 2010), 91-98.

101 Rudolph Arnheim, Entropy and Art: An Essay on Disorder and Order (Berkeley: University of California Press, 1971), 44-45; this path is not followed in Jones, "Entropies."

102 Heinz R. Pagels, The Dreams of Reason: The Computer and the Rise of the Sciences of Complexity (New York: Bantam Books, 1988), 54-70; Seth Lloyd and Heinz R. Pagels, "Complexity as Thermodynamic Depth," Annals of Physics 88 (1988): 185-213.

103 Rosalind Krauss, "The Grid, the /Cloud/, and the Detail," in The Presence of Mies, ed. Detlef Meetens (New York: Princeton Architectural Press, 1994), 133-47; Hubert Damisch, A Theory of /Cloud/ Toward a History of Painting, trans. Janet Lloyd (Stanford: Stanford University Press, 2002 [1972]).

104 In Elisa Pezzotta's Stanley Kubrick: Adapting the Sublime (Jackson: University Press of Mississippi, 2013), Kubrick's use of the sublime in 2001 and elsewhere is alluded to in a general and analytically loose manner, as a quality embracing terror, the marvellous and the supernatural (see especially 169-72).

105 Edmund Burke, A Philosophical Enquiry into the Origin of Our Ideas of the Sublime and Beautiful (London: R. and J. Dodsley, 1759 [1757]); Gary Shapiro links entropy and the sublime through a common antianthropomorphism, see Earthwards: Robert Smithson and Art after Babel (Berkeley: University of California Press), 151. 
106 Smithson, “Donald Judd” (1965), in Robert Smithson: Collected Writings, 6.

107 Clarke, The Lost Worlds of 2001, 41-43; Geduld, Filmguide to 2001, 24.

108 Gilles A. Tiberghien, Land Art (New York: Princeton Architectural Press, 1995), 48-49 and 67; Heizer, Sculpture in Reverse, 14 and 36; Rosalind E. Krauss, Passages in Modern Sculpture (Cambridge (MA) and London: 1977), 280.

109 Reproduced in Tiberghien, Land Art, 23, III. 2. In Smithson's own posthumously realised Amarillo Ramp (1973), Tecovas Lake, Amarillo, Texas, the ramp is shaped like a spiral.

110 Tiberghien, Land Art, 53, III.2 and Suzaan Boettger, Earthworks: Art and the Landscape of the Sixties (Berkeley, Los Angeles and London: University of California Press, 2004), 88-89.

111 Brian Aldiss, Earthworks (London: Methuen, 1965); Boettger, Earthworks, 129-53; Rice, Kubrick's Hope, 32.

112 J.G. Ballard, "The Voices of Time" [1960], in The Voices of Time (London: J.M. Dent and Sons, 1984 [1963]); http://www.ballardian.com/ cosmic-sentinels-spiral-jetties-ballard-smithson-dean

113 Patrick Werkner, Earth Art USA: Von den Ursprungen zu den Grossraumprojekten in der Wüste (Munich: Prestel, 1992), 19-22.

114 Geduld, Filmguide to 2001, 60.

115 "The Crystal Land," 9.

116 Jack Burnham, Beyond Modern Sculpture: The Effects of Science and Technology on the Sculpture of this Century (New York: George Braziller, 1967).

117 Burnham, Beyond Modern Sculpture, 9 and 370-76.

118 Burnham, Beyond Modern Sculpture, 371.

119 Hutchinson, "Science-Fiction," 34 and 41.

120 "The Art as Shaman," in Great Western Salt Works: Essays on the Meaning of Post-Formalist Art (New York: George Braziller, 1974), 139.

121 Lucy R. Lippard, Overlay: Contemporary Art and the Art of Prehistory (New York: Pantheon Books, 1983).

122 Ordway and MacGowan, Intelligence in the Universe, 301.

123 Krauss, Passages in Modern Sculpture, 239-42 and 267-79; Rosalind E. Krauss, The Originality of the Avantgarde and Other Modernist Myths (Cambridge (MA) and London: MIT Press, 1985), 261-64; James Meyer, Minimalism: Art and Polemics in the Sixties (New Haven and London: Yale University Press, 2004), 160-62.

124 David Bordwell, Janet Staiger and Kristin Thompson, The Classical Hollywood Cinema: Film Style and Mode of Production to 1960 (New York: Columbia University Press, 1985), 6 and 50-58; See especially 50: "In making narrative causality the dominant system ..., the classical Hollywood cinema chooses to subordinate space." Ralf Michael Fischer, Raum und Zeit im filmischen Oeuvre von Stanley Kubrick (Berlin: Gebr. Mann Verlag, 2006), 13-15 and 44-49.

125 Gelmis, "The Film Director as Superstar," 47.

126 Fischer, Raum und Zeit im filmischen Oeuvre von Stanley Kubrick, 13-14, 263-65 and 301; Kolker's characterisation in A Cinema of Loneliness, 117-18, could also be about minimalism: "On an important level, it is a film about design-about size, texture, and light, about the ways that objects within a cinematic space are delineated, ordered, shaped, and colored, and about how human figures interact with those objects."

127 Smithson, "Entropy and the New Monuments," in Robert Smithson: Collected Writings, 19-20.

128 Michael Fried, "Art and Objecthood," Artforum 5 (Summer 1967): 12-23, reprinted in Gregory Battcock, ed., Minimal Art: A Critical Anthology (New York: E.T. Dutton, 1968), 116-47; Meyer, Minimalism, 229-42. In a "Letter to the Editor," Artforum (October, 1967), reprinted in Smithson, Robert Smithson: Collected Writings, 66-67, Smithson criticised Fried's observations.

129 Sol LeWitt, "Paragraphs on Conceptual Art," Artforum 5 (Summer, 1967): 79-83; Robert Morris, "Notes on Sculpture, Part II," Artforum 5 (October, 1966), 20-23, reprinted in Battcock, Minimal Art, 228-35 (citation 234).

130 Carl Andre, exh. cat. (The Hague: Haags Gemeentemuseum, 1969), 5. 